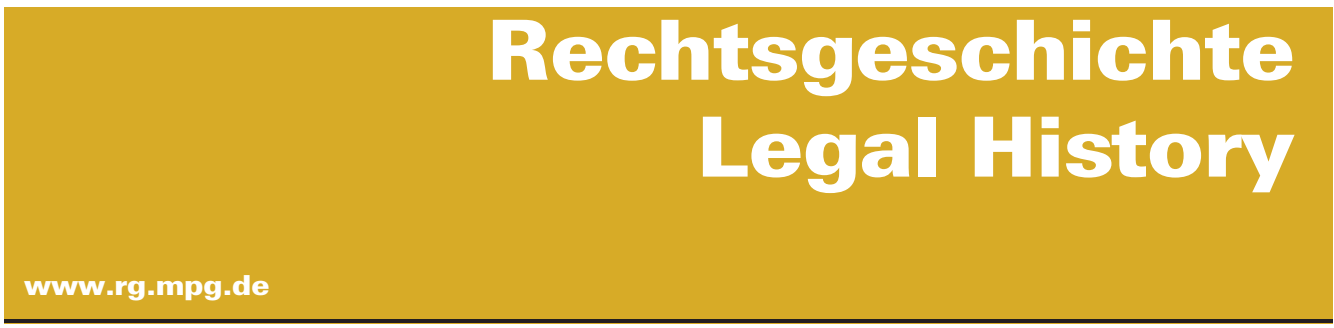

http://www.rg-rechtsgeschichte.de/rg22

$\mathrm{Rg} 22201490-118$

Zitiervorschlag: Rechtsgeschichte - Legal History Rg 22 (2014)

http://dx.doi.org/10.12946/rg22/090-118

\title{
Raja Sakrani
}

\section{The Law of the Other}

An unknown Islamic chapter in the legal history of Europe 


\section{Abstract}

As the Other is indispensable for the construction of self-identity and collective identity, the question of the Other is viscerally linked not only to the question of identity but also to law. Starting from some reflections in philosophy about Otherness and the sociological inquiries of building collective identities a fundamental problem remains: Who is the Other? Or: What does Europe have to gain from rediscovering the History of the Muslim Other and his normative space in order to understand his collective identity and to resituate his Otherness in an inclusive plural albeit value oriented Europe?

There is no doubt that historians recognize the decisive role played by translations and Arab thought for the reception of the heritage of Antiquity and Greek philosophy. But don't they remain blind about the role of the evolution of the realm of normativity in Europe?

In order to tackle this complex question some Islamic pasts will be remembered in a first step (I). Then a further look is thrown upon Islamic Law in the History of European Law (II), whereas the case of Spain is analysed as a problem of interacting and overlapping legal cultures on the basis of a critical analysis of research traditions (III). New challenges arise for a more complex understanding of a selective collective memory on the one side and the necessity to improve our knowledge of this entangled normative history beyond the case of AlAndalus on the other side in: Sicily, France, England and East Southern Europe. 


\section{Raja Sakrani The Law of the Other}

An unknown Islamic chapter in the legal history of Europe*

Others are also an Other themselves. The Other reveals ourselves to us. It fascinates us and attracts us, but at the same time repels us. It is "proche et lointain ${ }^{\mathbf{1}}$ - »close yet far «. But the Other also makes normative judgments and condemnations. Sartre famously formulated this ambiguity as: »'enfer c'est les autres «. ${ }^{2}$

The problem of the Other has been unrivalled since the Greeks. It oscillates between a subjectivity that is to be rejoiced through love and tenderness and another that is to be reduced - by force, if necessary. ${ }^{3}$

To get it out of the way: the Other is a disturbance because it provokes knowledge which, however, presupposes an encounter; this encounter is difficult because it occurs through difference and not through reciprocal mimicry. ${ }^{4}$ If the Other disturbs us, it is because he refuses to be locked into the sphere of sameness by us, because he refuses to conform to our rules and our stereotypes.

Emmanuel Levinas casts the Other as the very fundament of ethics. Being an "absolute other « 5 and absolutely transcendent, the face of the other questions the identity of the self through an ethical relationship that pierces the closure of the self. As the Other is indispensable for the construction of self-identity and collective identity, the question of the Other is viscerally linked not only to the question of identity ${ }^{6}$ but also to law. This gives rise to the question: What happens when I meet the Other face to face?

Emmanuel Lévinas said that the Other is a face. ${ }^{7}$ Yet the face of the Other necessarily leads us to its invisible features, to another truth which escapes us because it concerns what is absent and opens itself up to infinity. »Le >Tu ne tueras point est la première parole du visage ${ }^{\mathbf{8}}{ }^{\mathbf{W}}$ We shall shortly see how in the history of Europe, Muslims were often invisible - transparent despite their physical visibility. That is to say the problem of the nonEuropean Other, the extra-European or, to put it more precisely, Muslims, on the legal plane concerns an encounter with an Other understood as an end in itself; ${ }^{9}$ this encounter precedes the perception of the Other as a persona, i.e. as a legal subject.
* The essay represents an extended version of a lecture I held at the MPI in September 2013; Johannes Nanz was kind enough to translate it into English. I am also grateful to Jenny Hellmann for her assistance in providing relevant texts and in compiling the bibliography.

1 Baudelaire (2001).

2 SARTre (1962). Huis clos is, of course, a very well known play created May 27, 1944 in the theater du Vieux Colombier in Paris. Several years later, Sartre himself proclaimed that his famous reply: "L'enfer c'est les Autres « had always been misunderstood. „On a cru que je voulais dire par là que nos rapports avec les autres étaient toujours empoisonnés, que c'était toujours des rapports infernaux. Or, c'est autre chose que je veux dire. Je veux dire que si les rapports avec autrui sont tordus, viciés, alors l'autre ne peut être que l'enfer. Pour- quoi? Parce que les autres sont au fond ce qu'il y a de plus important en nous-mêmes pour notre propre connaissance de nous-mêmes.« Text spoken by Jean-Paul Sartre in the preamble to the phonographic recording of the play in 1965 . The texts were collected by Contat / Rybalka (1992).

3 Concerning the Other, the being constitutes a fundamental dimension of human existence, Voelke (1961) 11.

4 Compare this to Shakespeare's observation in Hamlet that to judge another is to judge oneself. On Hamlet and the law, cf. Ost (2012), Shakespeare, La Comédie de la Loi, 259-282.

5 The absolute other is the Other. Cf. the chapter: Métaphysique et Transcendance. Désir de l'invisible, in: LeVINAS (2006) $21 \mathrm{f}$.

6 »Le prétendu scandale de l'altérité, suppose l'identité tranquille du Mê- me, une liberté sûre d'elle-même qui s'exerce sans scrupule et à qui l'étranger n'apporte que gêne et limitation. Cette identité sans défaut libérée de toute participation, indépendante dans le moi, peut cependant perdre sa tranquillité si l'autre, au lieu de la heurter en surgissant sur le même plan qu'elle, lui parle, c'est-à-dire se montre dans l'expression, dans le visage et vient de haut «. Levinas (2006) 222-223.

7 And »le visage parle«, Levinas (1982) 92.

8 Ibid., 93.

9 In the Kantian sense. 
As we all know, Roman lawyers borrowed this term from the Greeks who used it to refer both to the physical reality of a person and to the abstract figure of a real person who could take on various guises through "masks" in the antique theater according to the role they symbolize. ${ }^{\mathbf{1 0}}$ This is the reason why we are - the construction of Roman law willing - legal actors. In this game, which does not work without exclusion, the question remains: Why do we have a tendency to exclude the Other with his masks and faces? Is it the fear of losing our touch-points such as Christianity and our identity, the comfortable situation which makes us what we are? Or do we gain our identity from this distance, from this difference? To put it more clearly: What does Europe have to gain from rediscovering the History of the Muslim Other and his normative space on European ground today?

The essentials of the European legal narrative focus on the process of rationalization and the role of Roman law in the $19^{\text {th }}$ Century codifications. In fact, the formation of Europeanization in its normative and identitary dimensions excludes any extra-European legal interference from the outset. And yet socio-legal traffic between European soil and the Orient have been flourishing for 14 centuries. Is our memory selective and faulty? Why does one admit to the decisive role played by translations and Arab thought for the reception of the heritage of Antiquity and Greek philosophy ${ }^{11}$ but remain blind - as concerns to normative - to the history of Islamic law in Europe? This question - which was unthinkable just a few years prior - is not intended as a simple provocation today. Rather, it expresses an urgency that is scientific, legal and human. This requires, as we will see, an interdisciplinary approach.
I. Islamic pasts in Europe: A problem of historiography or of Otherness?

History smiles, perhaps, on its victims and on its heroes. It simply passes. One thing is for certain, however, we do not know all its versions. Some have been suppressed by the words and clamor of others. And then there are those that have been truncated, reduced or simply buried under contemporary history. There is no doubt that historiography has to be selective for methodological reasons. That is one of Weber's legacies to legal history. But the direction of selectivity is steered, according to Weber, by interests and values. To this extent, the question is about the Kulturbedeutung of a nearly complete denial of an important part of European history.

The category of the Other - in the philosophical sense - carries within it the self-deployment of thought. This goes beyond Hegel's perception, who regarded the Other as the motor of any dialectics. ${ }^{12}$ It is true, however, that within European culture, the Other has long been under the influence of a universal developed from the unique experience of Europe. Today, questioning history, and legal history in particular, is not only an urgent task, but also one legitimated by the rarity of legal research $^{\mathbf{1 3}}$ when compared to anthropological studies that seek to move the world's center of gravity away from its Western focus. To imagine a cultural and legal Other is first and foremost to free the diversity of cultures from its dependence on European culture. However, such an act constitutes both a problem and a challenge for research into the history of law - in particular - as leaving Eurocentrism ${ }^{\mathbf{1 4}}$ behind should not be understood as a juxtaposition of Others. The case of Islam and Islamic law is the typical example. The truncated passage from European universalism to some form
10 Personne, Dictionnaire de la Culture juridique, Alland / Rials (2007) 1151.

11 There is abundant literature on this subject. See, for example: Agrus / Hitchсоск (1994); AsAd/ZBindeN (1960), esp. 99-121; Copleston (1954) 186-211.

12 According to Hegel, the Other promotes substance - working negatively from the inside - as a subject and discovers a becoming for him as one can only become oneself by way of the Other. This logic is extended by George Herbert Mead in his famous model of »taking the role of the other « in order to gain one's identity. Cf. Mead (1934).

13 It goes without saying that law - as a central pillar, if not the very fundament, of the construction of nation and identity - is more hermetically sealed off from legal cultures of the Other. The identitary function of law is thus linked to the birth of the nation state. This function is often un- derestimated in the functional catalog of law. On this subject, cf: Gephart (2012b) 19-53.

14 This is the ambitious project formulated in Thomas Duve's latest writings. See particularly: Duve (2012) 18-71. 
of idle essentialism or relativism only pushes Islamic culture to rely more on itself, on what constitutes its hard core: religion.

For several years now, several historians and social science researchers have been tackling the topic of Europe and its past relations to Muslims and the Islamic world. Recent works showcase a great leap in perspective and method. Other, older works, are increasingly dusted off and emerging or waiting to be retrieved - from the vaults of oblivion. Consciousness of Islamic facts and norms has developed but very slowly. Europe took some time to understand that this is not a temporary phenomenon on its soil, and begin to understand what was happening. With fundamentalism that continues to gain momentum since the seventies, September 11, 2001, the wars in Iraq, Afghanistan, Africa and elsewhere, the semantic interference has now reached its peak. The adjective "Islamic « is larger than that of "Muslim « because it refers to cultural and social elements within the Islamic world (Islam writ large) or what we shall call Islams that comprises both Muslims and non-Muslims, i. e.: Jews, Armenians, Oriental Christians, etc.. These elements also have had a massive presence on the European continent for centuries. The adjective "Muslim«, in turn, refers to the Muslim religion and thus to the religious sphere.

This categorization, which is indispensible for the following analysis, does not resolve all the ambiguities and misunderstandings surrounding forms of Islam or Muslims. »Behind the words Islam and Islamism exists a multiform reality of a billion people on several continents, made up of societies that are extremely different and that crisscross heterogeneous cultural regions which sometimes do not communicate with one another «. ${ }^{\mathbf{1 5}}$ From Morocco to Indonesia and China via the Maghreb, sub-Saharan Africa and the heart of Europe, along with its Slavic extensions and the peoples of the former USSR; the Middle East, Turkey or India, Pakistan, Afghanistan and Iran; in each place, Islam has adapted to languages, customs, and distinct local features and has, in fact, turned into Islams capable of forming pluralism. The only problem is that the varying degrees of hybridization have not completely changed the hard core of theology and law. Space precludes an in-depth analysis of this colossal issue. Just to quickly touch upon the problem - and this can merely open an immense and revolutionary field of research, that requires new literature and a new understanding of Islamic law and the radical differences in Islam on a psycho-analytical level - that religious extremism is driven »by an impulse, and this impulse is simply the inverse of the desire to be an other «, ${ }^{16}$ what Kierkegaard put as follows: »this despair wills to be itself «. ${ }^{17}$ The best way to put it is that the legal history of the Islamic past in Europe faces a large project. Europe is urgently called upon to take the issue of otherness in its legal sense headon, ${ }^{18}$ to finally begin a serious scientific study of Islamic normativity on European soil.

Let us start by tracing out the current Muslim presence in Europe and its legal reverberations. There are 17 million Muslims living in Europe today, according to Valensi, a third of which live in France. ${ }^{19}$ Generally speaking, most admit to the immigration of Muslims to Europe as something that developed during the $20^{\text {th }}$ Century, firstly due to World War I, when the old continent needed soldiers for its armies and then following World War II due to economic growth and the requirement for more labor. This very wide-spread perception in the minds of Europeans is quite far removed from historical reality. The presence of Muslims on European soil is much more firmly anchored in the history of Europe and even goes beyond the crusades and the religious conquest of the Iberian Peninsula. To know the Arabo-Islamic heritage - including the normative one - in Mediterranean Europe (and not only there), is to assume a double rupture: with the blindness and reticence of social sciences as concerns Islam and with the current state of interdisciplinarity, which by necessity needs to include law that, to date, has
15 Benslama (2009) 5.

16 BensLama (2009) 5.

17 KierkegaARD (2013) 73.

18 Transferring the pathos of "Otherness « and its foundation in »the right to rights« (Hannah Arendt) to Muslims in the emerging Europe enor- mously profits from the powerful

book of BЕNHAвIв about the rights

of Others (2004).

19 VAlensi (2012) 7. 
remained absent. Need one recall that this subject has become a real issue for archeology? ${ }^{20}$ Or that the contributions of Arabo-Islamic engineers, traders, doctors, philosophers and artists to European science, technology, philosophy and theology does not simply wipe out those made by the numerous Muslim lawyer-theologians in Europe. ${ }^{21}$

It is true that this particular historical situation following the war led to an unprecedented phenomenon in the history of Islam. For the first time, Muslim communities constituted a minority outside the dar al-islam (House of Islam). What's more, this is a phenomenon that is quite interesting from a normative perspective. This is demonstrated by new legal literature that started appearing from the 1990s on - in both Arabic and English. In the USA, it was pioneered notably by Mohamed Jabir alAlwani and in the Orient by Cheikh Youssef AlQaradawi and many others. The literature is addressed to the Muslim minorities in the dar al harb (House of War). The Arabic name for this legal doctrine is fiqh al-aqalliyat (minority jurisprudence). I shall not further elaborate on this very complex legal phenomenon. ${ }^{22}$ Suffice it to say that it is still under development and will one day certainly form part of the legal history of Europe.

We shall now briefly depart from legal analysis in order to recall some basic facts about the Islamic
20 This is evidenced by a recent international conference organized by Inrap (Institut national de recherches achéologiques preventives) from September 11 through 142013 (Héritages arabo-islamiques dans l'Europe méditerranéenne - Archéologie, histoire, anthropologie) in Marseille: Villa Méditerranée et MuCEM (Musée des civilisations de l'Europe et de la Méditerranée). That historiography depends on the countries is a fact. On the other hand, if one takes into account that apart from Spain, where the imprint of al-Andalus is considered an important civilizational fact (albeit one that remains insufficiently studied), and that the heritage of Arabo-Islamic presence in Southern France remains poorly researched and subject to resistance - much like in Italy and Portugal, where this presence was also both important and lasting -; if one takes all this into consideration, European knowledge in all disciplines needs to be challenged: Why? What are they afraid of? Archeologists, historians and anthropologists have taught us: »les monnaies arabes et leurs circulations, l'archéologie funéraire, la présence de mobiliers archéologiques ou de céramiques importées, les épaves en mer, révèlent également des échanges d'un autre type, et livrent de nouveaux éléments de discussion sur la complexité de ces relations" INRAP (2013); the entire cultural and normative plane needs to be revisited and, above all, seriously and scientifically explored.

21 Certainly, the history of law will have to enter into dialogue with other disciplines. What they have to offer directly on law through the discovery or translation of Islamic legal texts is indispensable. The case of Spain - AlAndalus - is undoubtedly emblematic. My last research stay in Andalusia in February 2014 revealed the extent to which, in Granada, for example, the enormous corpus of Arabo-Islamic texts is insufficiently drawn upon as can be seen in the archive of the Alhambra itself. Moreover, churches and monasteries are still in possession of many documents that are difficult to assess. This issue becomes even more complicated when dealing with legal or theological texts: There seems to be a sort of amnesia surrounding the period before 1492. As if texts from the Islamic, gypsy, and Jewish history of Al-Andalus predating 1492 was but peripheral or very secondary. There is sometimes even a tendency towards kitsch that does not go beyond wonder towards the Alhambra or the tourist industry. That said, efforts to translate Arabic texts have taken up steam (archives, research centers, etc.). Therefore, it behooves me to express my profound gratitude towards Alejandro Martínez Dhier (Historia del Derecho, Universidad de Granada), David Torres (Archivo de la Chancillería Real), Amalia García Pedraza (Archivo del Colegio Notarial de Granada) for their time, their generosity and discussions rewarding for my research. Further, the recent opening of several social science disciplines that enable the elaboration of a cultural and anthropological history of mutual exchange between Europe and Islam promises to deliver a positive impetus to the history of law. Nevertheless, one should keep in mind that the complexity of the Islamic normative corpus - which is not confined to purely legal norms - renders interdisciplinary efforts absolutely necessary. For instance, archaeology contributed through recent discoveries of Muslim papers, money and other objects in France, sometimes difficult to date (such as in the Ruscino site in Perpignan), as well as steles found in Montpellier. Unfortunately, the steles were found in buildings, so that it remains unknown if they were graves like those discovered in Nimes. In the case of Nimes, study of the form of pits, niches, DNA extracted from the skeletal remains found as well as the position of the skulls, which looked to the South East, therefore, to Mecca, confirm the existence of Muslim groups permanently installed, capable of practicing the rites, Islamic legal and religious rules in cemeteries dating back to the $8^{\text {th }}$ and $9^{\text {th }}$ centuries, as Yves Gleize and Jean-Yves Breuil have pointed out in their presentation »Analyse archéo-anthropologique de trois inhumations musulmanes du haut Moyen Âge à Nîmes" at the conference mentioned above (Héritage arabo-islamiques dans l'Europe méditerranéenne). See in this context the works of RolandPierre Gayraud, Bernard Romagnan, Catherine Richarté, Sonia Gutiérrez Lloret ...

22 See the analysis in: SAKRANI (2013) $406 \mathrm{f}$. 
past of Europe. Let us begin by searching for the names and faces of the Other. Essentially, several denominations of Muslims appeared in Europe. They were called »Mohammedans« because European Christians insisted on highlighting their religious affiliation. ${ }^{23}$ Without getting into how such a connotation that evokes a cult of the Prophet that simply does not exist in Islam is to be categorically rejected, it is useful to point out one interesting ramification of this label as concerns law. Europeans spoke of "Mohammedan law « - an improper title as the Prophet has nothing to do with the construction of Islamic law. Not only did the legal schools first appear many years later, but the compilation of the Quran and even the quite problematic corpus of the hadith (the Sunna), so the words and acts attributed to Mohammed, postdate his death. That said, the expression »Mohammedan law « ${ }^{24}$ nevertheless continues to slip into certain European publications to this day. ${ }^{25}$ Muslims have also been described as »Turks«. Matters get more complicated here, as »Turk« can also refer to a function of the politico-military elite as well as to non-Muslims from the Balkans or the parts of Asia subject to the Ottoman Empire as well as to the Jewish, Armenian or Greek non-Muslims who resided in the Ottoman Empire itself. To top it off, European renegades were also called »Turks«, as to convert was to »become a Turk « or to »take the turban«. ${ }^{26}$ Turks »are distinct from the Moorish, urban Muslims and Arab-speakers and from the Arabs who populate the country-side", from the Berbers, the habitants of North Africa and in more general terms those active as Corsairs. ${ }^{27}$ In Spain, the last bastion of Islamic power in Europe, the lexicon is even more diverse and specific to an Iberian Peninsula that remained Muslim even after the fall of Granada in $1492 .^{28}$

In short, in order to identify who is Muslim in Europe from the $14^{\text {th }}$ Century on - or before -, and to try and follow the traces of Islamic law and its structures later diffused in the European normative corpus, one must necessarily take recourse to several recent historical studies. We shall briefly sum up the main points from which legal research could benefit.

In terms of semantics, Europeans during the Middle Ages used the expressions »Christianity«, »Christian world «, »Christian republic«, »Christian people«, "Christian blood« etc., which they opposed to Turks, »enemies of faith«, »enemies of Christians « or even »scourge of God «. ${ }^{29}$ It was only in the course of Enlightenment and a certain progressive tendency of secularization it engendered that it became possible to speak of Europe.

As regards Islam or Islamism, until very recently the usage referred to religion. This semantic deviation in Europe has led to major perversions and difficulties for research and even for the judicial system. Suffice it here to give two French and German examples. Since the $17^{\text {th }}$ Century, the French term »islamisme " has denoted religion itself, following the example of Christianity or Judaism.

Given that the term expanded to cover activism and extremism, however, we no longer have a term to refer to the religion of Islam in the strict sense. There remains the word Islam, but this has the inconvenience of being a catchall, referring to the aggregate of people who profess the faith, Islamic civilization, and the religion itself (...) just as we might refer, for example, to certain fascist movements that promoted the Christian religion as forms of $>$ Christianismer $(\ldots) .^{30}$

This confusion, sometimes sanctioned by imminent European specialists on Islam, ${ }^{31}$ prohibits distinguishing between the militancy of political
23 VALENSI (2012) 11.

24 On the body of Islamic legal provisions developed in colonial Northern Africa, see e. g.: VAn Eerde (1927); Perron (1848-1854); Bousquet (1947); Morand (1916).

25 The French founder of Sociology deserves attention in this context. Émile Durkheim himself does not seem to refer to Islam, except when he says in a letter to Richard Gaston, dated 1899, and with a negative tone: »Sur le mahométisme, je ne me prononce pas, vu le peu de données que j’ai.“ Durkheim (1975) 10.

26 Valensi (2012) 12. One might follow up on this by pursuing an interesting parallel concerning the identification of clothing with new converts to Islam, who grow ever more numerous in Europe and virulently call for the application of the Sharia.
27 Idem. See also on Muslims, moriscos, Moorish and Blacks: Almeida Mendes (2011) 143-158.

28 See for example: Martín Gutierrez (n. d.); González Palencia (1929) 118 f.; Perez Boyero (1997) 263 f.; and particularly the rich contribution by Asín Palacios (1940).

29 VAlensi (2012) 13 and 9.

30 Benslama (2009) 41-42.

31 To cite but one example: Roy (1999) 10. 
Islam up to the legitimacy and the use of violence on the one hand, and the phenomenon of Islamic faith with its dogmas and rites. German semantics, in turn, suffer from a wholly different problem: the indirect impact of the experience of Nazism on the term »Muselmann «. Since the $19^{\text {th }}$ Century, Hering ${ }^{32}$ wrote and composed a Kinderlied cautioning children against drinking coffee and highlighting the compromising usage of the words Muslim and Turk. Coffee was accused of weakening the nerves and essentially rendering its drinker »blaß und krank«: »Sei doch kein Muselmann - der ihn nicht lassen kann «. ${ }^{33}$ Muslims are thus depicted as dependent beings. Coffee is, in fact, but a veil concealing something else: the relationship to religion. The appearance of this song in $1934^{34}$ coincided with the start of the national-socialistic dictatorship. It was spread widely throughout schools and youth groups. The matter then took a tragic turn in the concentration camps: Der Muselmann took on a meaning in the extermination camps signifying that the person in question had become submissive to such a degree that he was but a bodily shell without a soul. The work of Agamben recalls this usage. ${ }^{35}$ The identitary consequences of this linguistic usage now also concern trials. ${ }^{36}$ The problem is the following: firstly, it seems from the circumstances of the case that the defendant had been unaware of the Nazi usage of the term Muselmann, so that the German justice system is called upon today to resolve complex problems that touch upon the identity of Muslims living on its territory and are linked to collective unconsciousness (and not consciousness). This is an extremely complex task. Secondly, the word
Muselmann / Muslim is not wrong per se - it is, in fact, linguistically quite correct, as evidenced by how it does not pose any problems elsewhere in Europe - but the twisted usage in a specific historical context renders it charged with perverse and ambiguous connotations and therefore unusable.

Sociologically speaking, with the exception of Spain, Muslims in Europe never formed compact communities the way they do today. Their - at times extreme - diversity, mobility and fluidity makes such a categorization impossible. Moreover, even the example of the Iberian peninsula is more complicated as the Muslim groupings and communities "were infinitely more diverse than religious and political authorities liked to think $« .{ }^{37}$ As historical research is increasingly revealing: While the presence of Muslims throughout the Europe of yesteryear certainly differed from that of today, this presence has been more constant and diverse than expected. All around Mediterranean ports in the north and south and even at the far end of the European continent, Christians and Orientals of all origins and religions are woven together by a proximity rooted in both familiarity and solidarity and in domination or repression. Cooperation among merchants, solidarity between shopkeepers and Muslim slaves, Muslim diplomats and voyagers occurred throughout the continent. ${ }^{38}$ Such ties clearly also appeared in Muslim countries: there were Christian slaves, captains of ships, consuls, and merchants. ${ }^{39}$ To put it succinctly: despite the domination of one group by the other, despite the enslavement of one through the other, despite the massive and violent expulsion in the case of Iberia, Muslims have for centuries been close foreigners in
32 Karl Gottlieb Hering (1766-1853).

33 The complete verse reads as follows: Trink nicht so viel Caffee

Nicht für Kinder ist der Türkentrank, schwächt die Nerven, macht dich blass und krank. Sei doch kein Muselmann, der ihn nicht lassen kann.

34 This melody appeared in the Liederbuch: Die Weiße Trommel, CLEFF (1934).

35 Agamben (2003).

36 In 2009 in Bavaria (Fürstenfeldbruck), the court ordered a merchant a 1200 Euro fine because he had used the term »Muselmann« in a disrespectful and ironic email (»Wir warten schon lange auf einen Musel- mann für unser Auto«) in such a way that the addressee felt insulted. The Court held: »Er wollte damit ... auch eine soziale oder rassistische Minderwertigkeit des Geschädigten zum Ausdruck bringen. Eine wertneutrale Auslegung der Bezeichnung >Muselmann` als altertümliche Bezeichnung für Moslem war ... nicht gewollt" (43 Js 12865/09). See further the very interesting reactions on the internet on the site: http://www.pi-news.net/ 2009/08/moslem-darf-nicht-musel mann-genannt-werden/.

$37 »[. .$.$] relèvent infiniment plus diver-$ ses que ce que les autorités religieuses et politiques n'ont voulu le croire«, VALENSI (2012) 14.
38 See, for example: Martínez Torres (2008) 39 f.; Pedani (1994) 56f. (on the complex issues of human trafficking, Muslim and Christian slaves, liberation treaties ...); Remie Constable (1994), cf. esp. 52-111 and 240-258; Hitzel (2011) 33-54; KAISER (2013) 251-272; Bono (1999). On the baptism of Muslim slaves in Italy, see for example: Aymard (1973) 49-64.

39 Соцомво (2011), see particularly 159-165; Maziane (2007) 256 f.; VALENSI (1967) 1268; KAISER (2011) 417-442. 
Europe (»étrangers familiers«), as Lucette Valensi' latest book is titled. Several historians submit evidence of this:

En Italie, Salvatore Bono dénonce un véritable tabou qui empêchait de percevoir les musulmans dans la société (...) nombreux dans la péninsule depuis des siècles. Maria Pia Pedani, plus intéressée par les rapports de Venise avec l'Orient et par les échanges diplomatiques, insiste ... sur la longue fréquentation des territoires vénitiens par les Ottomans et les Persans. Nabil Matar, déplaçant l'observation vers l'Angleterre, y trouve un même degré de familiarité des britanniques avec des musulmans de toute sorte $(. . .)^{40}$

As Godrey Fisher humorously highlighted from 1957: Apart from the period of 1620-1682, Britain was at peace with the Barbary regencies from the 15 th to the 19 th Century up to 1816 ; it did not enjoy such peaceful relations with any Christian country, not even with Portugal. ${ }^{41}$ Hundreds of Turks spent long years in captivity »dans les campagnes de l'Empire germanique (...) tandis que des affranchis et des convertis se fondaient dans la population italienne ou française «. ${ }^{42}$

What one historian terms a culture d'antagonisme with reference to the history of religious confrontation in Europe ${ }^{\mathbf{4 3}}$ is certainly not the correct approach to studying Islamic law in Europe. Even leaving the major risk of Eurocentrism aside, such a depiction is simply historically wrong. Firstly, fratricidal wars between Christian monarchies or between Catholics and protestants or other Christian dissidents along with infighting between Muslim states ${ }^{\mathbf{4 4}}$ have led to many more massacres and casualties than clashes between Christians and Muslims. ${ }^{45}$ Secondly, - and apart from a lasting Arab-Islamic civilization well-rooted in the Iberian peninsula and the north shore of the Mediterranean - the presence of Muslims on European ground was not solely linked to religious conflict - or how else could one explain that a great number of Muslims voluntarily converted to Christianity, a phenomenon that has only been studied in depth for several years called les musulmans $d u$ Christ. Muslims who

quittaient leurs pays (dans la majorité des cas, il s'agissait de l'Afrique du Nord), leur culture et leur religion pour entrer dans un snouveau monder et devenir chrétiens. Leurs situations étaient diverses et variées: ils étaient esclaves ou bien hommes libres et étaient mûs par des raisons d'ordre social, économique ou bien religieux, ou par les trois facteurs réunis et imbriqués. ${ }^{46}$
40 This is Lucette Valensi's pertinent synthesis, Valensi (2012) 240. See also: Matar (1999) 22 f.; Matar (1998). On the peace treaty concluded between Venice and the Ottoman Empire in 1419 that foresaw reciprocal treatment of subjects of both parties, see: PedANi (2010) 211.

41 Fisher (1957) 11-12.

42 VAlensi (2012) 240.

43 Poumarède (2004). On the discussion of the Crusades and the dream of a universal monarchy unified by Christian faith, see esp.: 83-104. See in the same sense, and with reference to previous confrontations during the $12^{\text {th }}$ and $13^{\text {th }}$ Centuries: CARDINI (2000) 94-116.

44 »... guerres civiles en France (sept entre 1562 et 1585 ), guerre entre l'Angleterre et l'Irlande dans les années 1640 et 1650 , guerres dynastiques entre royaume de France et monarchie espagnole, guerre de celleci contre l'Angleterre, guerre de
Trente Ans dans l'Europe - ont été plus coûteuses et plus meurtrières que celles qui les opposèrent à l'Empire ottoman et aux États barbaresques. Le roi de France ne participe pas à la guerre maritime qui conduit à la victoire de Lépante et ne perd donc aucun sujet. Mais l'année suivante, dans la nuit de la Saint-Barthélemy, 2000 à 3000 protestants sont massacrés en plein Paris et qui sait combien dans les autres villes du royaume ...", VAlensi (2012) 11. Regarding the internal wars between Muslim kingdoms and states, the situation is equally dramatic. Medieval chronicles recount this in a celebratory tone: IbN AL-QALANISSI (1908); IBN ALAthir (1231/1979), see esp.: Vol. X, XI and XII on the Frankish invasions; Grousset (1934-1936); and see barbaric acts committed by both sides in the famous tale by MaAlouf (2008).

45 The literature both in this direction and in the inverse one is immense.
See just by way of example: On Great Britain's wars with "Christian« countries: FISHER (1957) 11 f.; Hegyi / Zimányi (1988), esp. the chapter »Ein halbes Jahrtausend in Wehr und Waffen«, 10-36; Laurens / Tolan / Veinstein (2009) note Chap. III, "Les figures de l'antagonisme«, 175-198; Colley (2003).

46 Соцомво (2011) 159. See also the instructive studies (just by way of example) by: Bono (1998) 429-445; LARQUÉ (1998) 391-404; ANGIOLINI (1997) 67-86; SCARAFFIA (1993). For a bibliographic study on the renegades see: BenNASSAR / BenNASSAR (1989); Bennassar (2009) 131-146 and BENNASSAR (1996). The case of converted moriscos is a very fascinating and complex topic on its own. Suffice it here to simply mention one interesting yet in no way unique case. Essentially, in 1572 ahead of the 5th general Congregation, a morisco joined the Company of Jesus: Ignacio de 
And how to explain that the Muslims who voluntarily - and certainly sometimes forcedly converted to Christianity could not escape violent expulsion from the entire Iberian peninsula between the $16^{\text {th }}$ and $17^{\text {th }}$ Century despite their Christian faith? ${ }^{47}$ Religious assimilation thus never was a conditio sine qua non to obtain social and, consequently, legal recognition. The Other thus remained a "social outsider" to paraphrase a concept developed by Pierre Vidal Naquet. ${ }^{48}$ Finally, to touch upon a very mystifying question: why was the stigmatization of Muslims and Protestants often linked? Research has yet to yield a satisfying answer.

For several reasons, then, the Islamic past in Europe has remained a historiographic blind spot for a long time. While differentiated answers are still outstanding, we now at least know enough to draw a preliminary conclusion. The facts are there:

une large partie des territoires aujourd'hui inclus dans l'Union européenne a été islamique, à un moment de son histoire. L'Europe a été partiellement islamique et donc partiellement musulmane. Ce cas de figure concerne l'Europe balkanique sous domination ottomane, laquelle englobe la Grèce, avec Crète et Chypre; il concerne aussi Malte (...) une grande partie de l'Espagne et du Portugal ou de la Sicile ... La France du Sud a connu une domination musulmane. ${ }^{49}$

The anachronistic attempt to inscribe the "Christian roots of Europe" into the European constitution reveals both a challenge and a problem. A challenge for Europe that seems to be held hostage: it defines itself by constantly referring to a border of otherness occupied by Islam and strains to answer the questions: Can Muslims be
European? Can Europeans be Muslims? These questions go to the heart of the legal issue for European citizens as legal subjects. As for the problem, it simply leaves researchers from all disciplines confused: How to escape all types of political discourse that heatedly addresses the problems of integration and immigration, as well as the enforcement of Sharia that locks social scientists - but also lawyers - into a debate that is footed on the falsehoods of Christian or - at best - JudeoChristian roots of Europe.

\section{Islamic law in the history of European law}

European identity was constructed not only through one's own values, norms and institutions, but through the distinction with the Other. ${ }^{50}$ If the factual lengthy presence of Muslims in Europe is increasingly confirmed despite strained and hostile relations, any reflection on the aspect of how Islamic law played into the legal development of Europe remains ambiguous, if not inexistent. This is all the more surprising as one path to define what Europe »is « leads to an understanding of Europe as a »Rechtsgemeinschaft« (legal community), as Hallstein famously put it.

The index in Wieacker's grand study on the Privatrechtsgeschichte der Neuzeit ${ }^{51}$ makes no mention of the issue of Islamic law. Likewise, the parts on the reception of Roman law contain no reference whatsoever to any Islamic role or influence. The same goes for M. Wesel's Geschichte des Rechts in Europa ${ }^{52}$ which merely mentions the Reconquista while giving some legal meaning to centuries of Islamic presence and practice - including legal practice - in Spain. Matthias Schmoeckel
Las Casas (1550-1608), and became famous for his apostleship among the moriscos, Muslims, Jews and Christians in the Middle East and North Africa. See in this context: El Alaou (2006) 24 f.; Borja Medina (1988) 3-136. On the Hispanic monarchy, literature abounds. See for example: Alonso Acero (2006).

47 A comparison with converted Jews in Europe who could not escape extinction imposes itself.

48 Vidal Naquet (2009). The author gives full scope to the concept of the social Other. Through the pages of the book, the historian delivers a study on women, slaves, foreigners, or others excluded from the City, which allows us to understand the core of intellectual, feminine, political, etc. Other and sheds light on the operation of rites of passage and transgressions.

49 DAKhlia/Vincent (2013) 8.

50 For a general discussion of the highly debated concept of collective identity see Gephart / Saurwein (1999); with special reference to the problem of European Identity: GePHART (1999)
143-168. See also: Gephart / WALDENFEls (1999), in particular Giesen about »Coding collective identity«, 13-43 and MaLIK about »The construction of collective identities in Islam«, 206-229.

51 WiEAcKer (1967).

52 WeSEL (2010). 


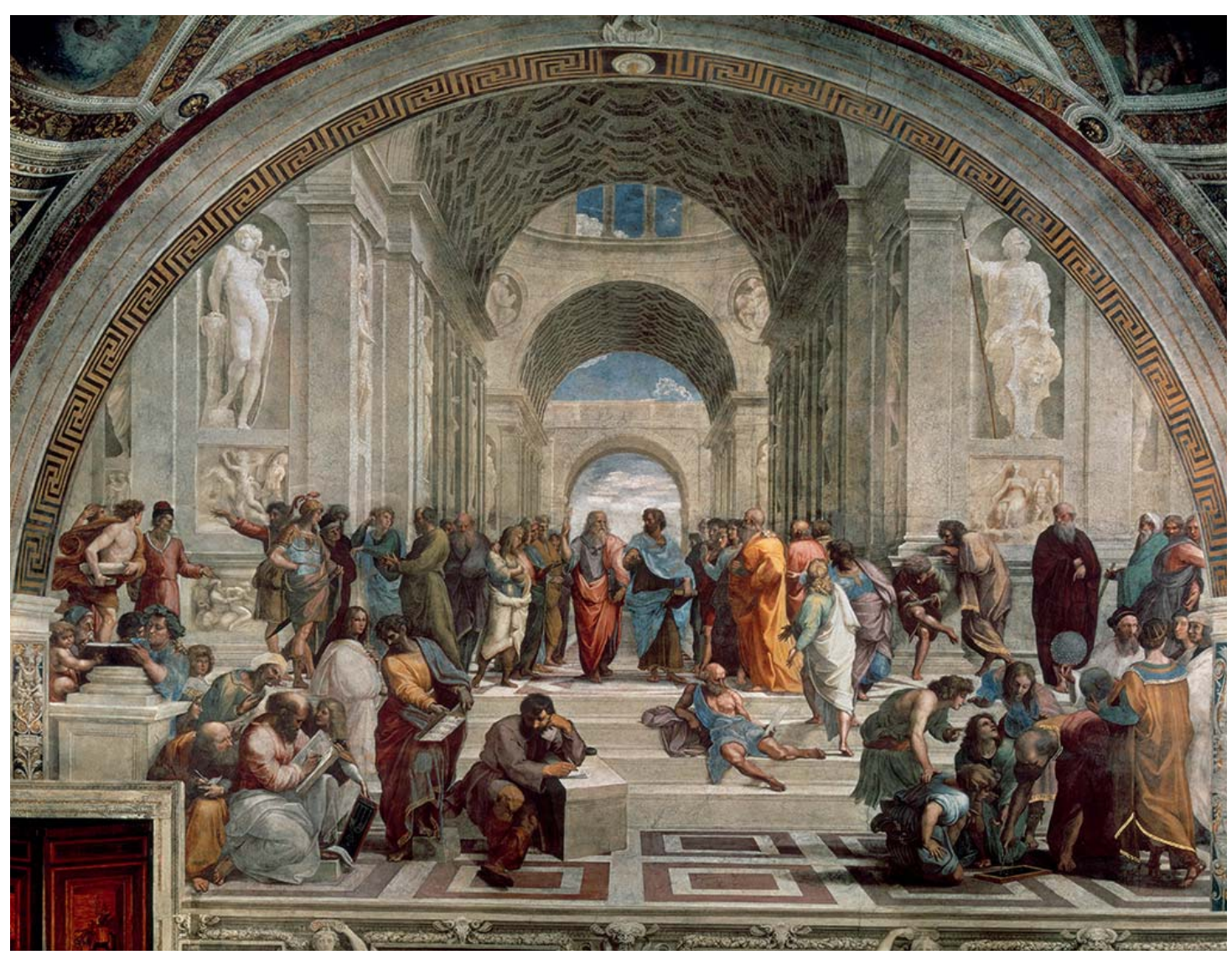

Figure 1: Raffael (Raffaello Sanzio), 1483-1520, The School of Athens. 1509/1510, Rome, Stanza della Segnatura @ ALINARIARTOTHEK

searches for these in his book Aufder Suche nach der verlorenen Ordnung, but does not mention the presence of a real or imagined law of Islamic provenance nor the fight against it. ${ }^{53}$ To be honest, this finding can be pretty much generally applied. The grand master behind l'Europa del diritto, Paolo Grossi, ${ }^{54}$ omits this debate during the very interesting section of his work on legal culture in Europe, despite his transcivilizational erudition. Without pretending to have exhaustively studied every publication on this matter, the present text shall concentrate on just a few manuals, to which to need to be added. Neuere europäische Rechtsgeschichte, by Hans Schlosser, who timidly touches upon the subject during two occasions: first, indirectly, under the title Recht der römischen Kirche, where he recalls the merits of Arab philosophers Ibn Sina (Avicenna 973/980-1037) and Ibn Rushd (Averroes, 1126-1192) ${ }^{55}$ in transmitting Plato and Aristotle within the »Islamic cultural space ${ }^{56}$ The recognition of the philosophical merits of Averroes has also been a major concern for European painters, who often approached this issue in a spirit of theological opposition or triumph (see Figures 1, 2 and 3). Nevertheless, he forgets to add that both of them are also legal scholars. Notably, Ibn Rushd, son of a judge (Qadi), exercised this function himself in his native Cordoba, later rising to

53 SChmoeckel (2005).

54 Grossi (2009).

55 SCHLOSSER (2012) 29

56 Ibid. 


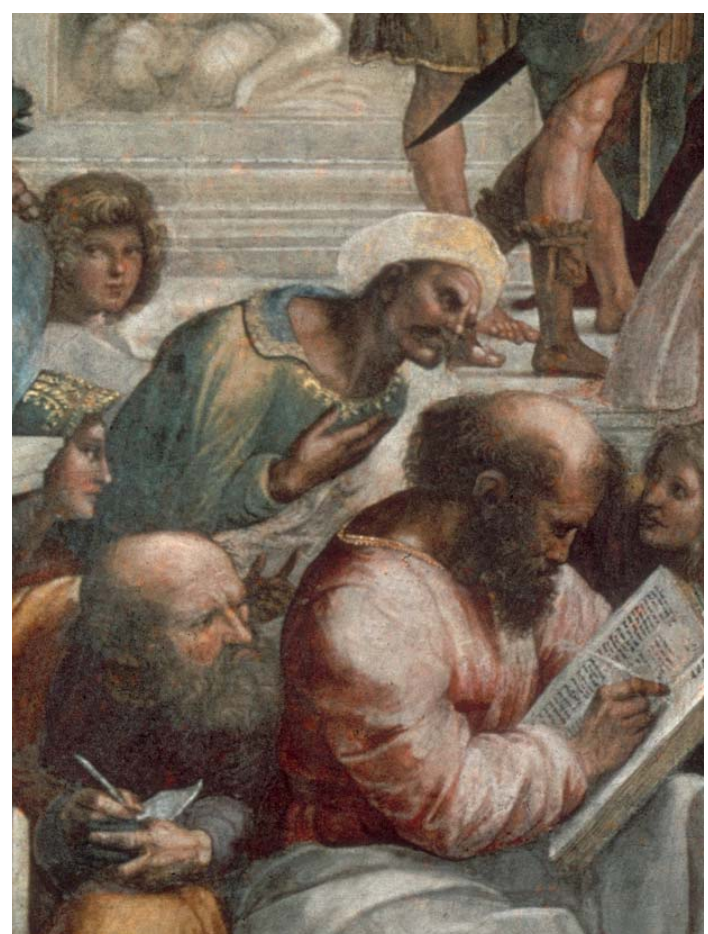

Figure 2: Raffael, The School of Athens, detail: Averroes (C) ALINARI-ARTOTHEK the position of minister of justice. The text remains silent on his major influence on the reform of judicial administration. ${ }^{57}$

The second brief mention concerns the first codification in the Islamic world, the Ottoman Majella from $1877^{58}$ as well as the Turkish reception of Swiss private law, neither of which are analyzed in any further detail. ${ }^{59}$ Hattenauer does not treat Muslim law as an element of European law, but the long passages on Sicily and especially Spain do contain one key phrase deserving of attention: "Das Abendland erlebte eine mohammedanische Rezeption, deren Bedeutung für das europäische Recht bis heute kaum erkannt ist. « ${ }^{\mathbf{6 0}}$ He also makes mention of the reception of »EuroEuropean« law in Turkey, which has not made the Turks Europeans, as we know from the debate on Turkey's possible accession to the European Community.

How might this unconscious oblivion or silence be explained? At least two explanations are worthy of being underlined. Firstly, the - apparently complete - negation by Wieacker remains present, albeit hidden and implicit. In order to describe the "proprium " of European law, the implicit reference to Weber, opposing occidental and extra-
57 Ibn Rushd (1126-1198). His complete name is Abu'l-walid Muhamed Ibn Ahmed Ibn Muhamed Ibn Rushd, born in Cordoba and died in exile in Marrakesh. He is the great commentator on Aristotle and contemporary of Maimonides (1135-1204), born in Cordoba and died in Cairo, the greatest Jewish thinker on the peninsula. Averroes is the archetype of the Muslim sage and erudite, even though he was mostly known as a doctor and philosopher. Before becoming a doctor during the time of the Almohad sultans Abu Yaqub Yusuf (1163-1184) and Abu Yusuf Yaqub Al-Mansur bi-llah (1184-1199), Averroes was initially a qadi (judge), then minister of justice. He left behind an impressive œuvre in the fields of law, theology, philosophy and medicine. It is to him that we owe the model idea, taken over by Renaissance thinkers later, that two truths, faith and reason, could neither be contradictory nor completely cancel each other out and that revelation and philosophy can be reconciled.
The contribution to law made by Ibn Rushd remains insufficiently explored. For Europe, recognition focused on philosophy - is generally timid or approached in a spirit of theological opposition or triumph. In the Arabo-Islamic world, he remains marginalized beyond specialized fields of studies and, paradoxically, remains at times less known than in the West. For a primer on these questions, see: Asín Palacios (1941) 15-72; Pasnau (2011); Aquinas (1270). On Averroes as one of the major actors in the theological and philosophical controversies in Islam, see for instance: CHebel (2006), 59-68 and esp. Chap. V: L'esprit de Cordoue. La tolérance en modèle, 84-96.

58 In reality, the Ottoman Majella is not a true systematic codification of civil law (contracts, torts, general principles of law, ...), but rather resembles a compilation of Islamic legal rules essentially inspired by the Hanafi school. Besides the Majella, legal mixing and legislative borrowing are two extremely fundamental phenomena in the study of both "pre« and "post « colonial Arabo-Islamic codifications. From the mid-nineteenth century, the Ottoman Empire had, in fact, embarked on a series of codifications even before the Majella, which were largely inspired by French law. This is the case for the Code of overland trade of 1850 and the Code of maritime trade of 1863 , the Penal code of 1858 and the code of penal procedure of 1879 . See: SAKRANI (2008) 463 and note 4 . On the crossing of Islamic and European sources, their colonial usage and legal hybrids: SAKRANI (2009). Cf. further: El Baz (1988-1989).

59 SChlosser (2012) 319.

60 Hattenauer (2004) 191. 


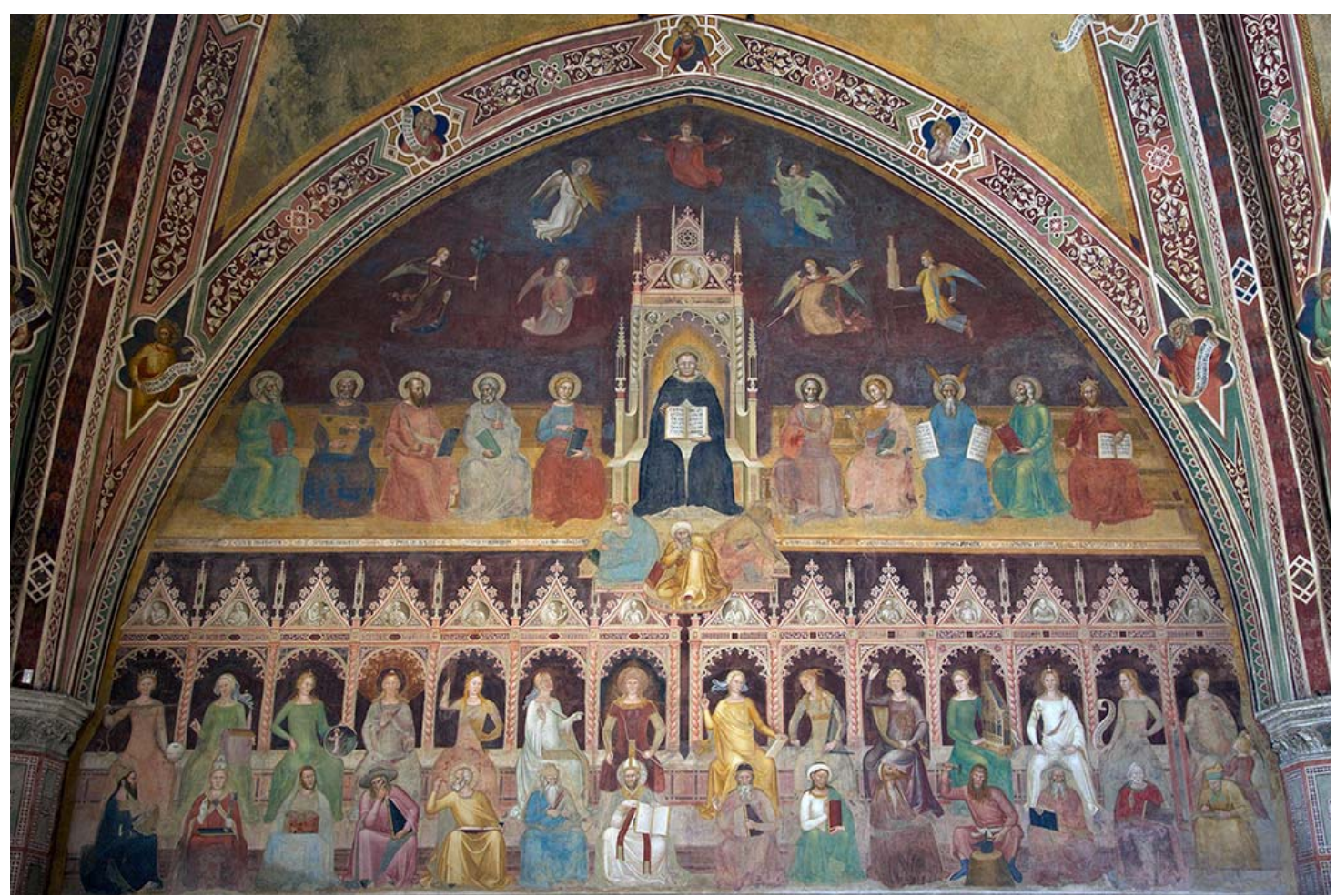

Figure 3: Andrea di Bonaiuto, 1365-1367, Triumph of St.Thomas and Allegory of the Sciences, Spanish Chapel, Basilica of Santa Maria Novella, Florence, Italy @ Peter Barritt/SuperStock

occidental legal tradition, seduces this author to exclude »the Other«:

Indem sie ein rationales Prinzip fand, das den gewaltsamen Austrag menschlicher Konflikte wenigstens innerhalb der Staaten ersetzte, hat die Jurisprudenz eine der wesentlichen Voraussetzungen für den Aufstieg der materiellen Kultur, besonders der Verwaltungskunst, der rationalen Wirtschaftsgesellschaft und selbst der technischen Naturbeherrschung der Neuzeit, geschaffen. ${ }^{61}$

Such a reading turns Qadi justice, and consequently its religious roots, into an inherent characteristic of Islamic law or a type of "validity culture« (»Geltungskultur«); ${ }^{\mathbf{2}}$ the interpretation further excludes any chance of rationalization from the outset - something that really is not in keeping with the meaning of Weber. Further, - and here I arrive at the second reason - irrationality has no place in the history of a civilization that declares and »self-describes « - itself rational. To put it more clearly, if in theory and socially any construction of an identity of self necessitates an Other, Muslims both in their real and imagined guises - and even every non-Muslim element that nonetheless belongs to the Islamic world is excluded by the irrationality and sometimes even savagery ${ }^{63}$ that is attributed to it.

All the above said, there are certain voices in Spain and beyond that have carried out a discourse
61 WIEACKER (1967) 69.

62 Cf. his latest contribution, GePHART, The concept of validity culture (forthcoming); see as a first formulation of the concept: GePHART / SAKRANI (2012) 103-137.

63 The savagery of the Arabs, Indians or Sub-Saharan Africans is a central ideology during the colonization, massacres and extermination carried out by the West. For the normative colonial example of France: »Depuis le début du XIXe siècle, une littérature ouvertement raciste souligne le caractère incivilisé ou mal civilisé de l'arabe, intimement lié à sa religion.
En effet, la `bestialité des indigènes musulmans est constamment soulignée pour légitimer la politique coloniale en matière juridique (...). Dans cet esprit, la politique coloniale française pratiquée en Algérie, en Indochine, en Nouvelle-Calédonie, en Afrique Noire a procédé selon une 
on the presence of Islam in the normative history of Europe. Besides Spain, such discussions have mainly taken place in Sicily and England, who are also affected by the underlying influence of Islamic law, not to mention France, the Balkans, etc. One of Richard Potz' most recent works is remarkable in this regard. ${ }^{64}$

III. Islamic pasts in Spain: A problem of overlapping legal cultures?

At the turn of the century and up to the 1940s, a new and remarkable historiographic and Arabistic perception of history pushed aside the Islamic past, buried and denied it. The past thus dissolved - or at least almost did, as the controversy has moved to Latin America and particularly Argentina ${ }^{65}$, , only to reappear at the end of the 1970s, so after the end of the Franco regime.

$$
* * *
$$

\section{Digression on mediators of cultures: interaction} and overlap of cultures

The Arabist Miguel Asín Palacios is certainly one of the key figures. His academic contribution continues to influence institutions, Arab and Islamic studies in Spain and elsewhere. Born in Zaragoza in 1871 and died in $1944,{ }^{66}$ his remarkable academic career, ${ }^{67}$ but especially his abundant, innovative and provocative works, have never ceased to elicit controversy. Asín Palacios had em- braced in his works a very vast field of historical, mystical, philosophical and even botanical ${ }^{68}$ research of Hispano-Islamic cultures.

Beyond a simple naive affiliation or superficial influences between religions and Islamic and Christian cultures, Asín Palacios offers with scientific rigor, with reference to Arabic or translated texts, relevant assumptions on complex overlap that span centuries between Islam and Christianity in their dimensions of mysticism, literature, linguistics, philosophy, sociology, etc. He offers an intellectual process which, while not wholly isolated from a whole Spanish movement with sometimes »European« dimensions, has, it must be admitted, remained quite timid and isolated. One need but recall the exchange of young Asín Pala$\operatorname{cios}^{69}$ with the man who assured in large part, from the late nineteenth century, European access to Islamic law: Ignaz Goldziher Isaac Yehuda, the founder of modern Islamwissenschaft and a source on Islam to Max Weber. ${ }^{70}$ His Sephardic ancestors settled in the seventeenth century in Hamburg, later in Berlin and Vienna to finally land in Hungary, where he was born. ${ }^{71}$ What is interesting about Goldziher, in addition to his extraordinary knowledge and recognition of Muslim religious authorities (who respected him to the point of naming him by the honorable title Shaykh) ${ }^{72}$ undoubtedly remains his merit of having tried, even if not always succeeded, in providing an impulse of Kulturgeschichte to Islamic studies including those centered on law. Then the question arises: was there an affinity between his work on sélection raciale«, SAKRANI (2012). See the passage $» \mathrm{Du}$ droit comme medium de conflit et de fragmentation normative. Le musulman sincivilisér et la >déjudaïsation ‘ des juifs: un cas algérien«, 245-246.

64 Cf. e.g. Ротz (2011).

65 Cf. the following analysis.

66 His family, which settled in Zaragoza, originated in Aragon and Rioja. For a comprehensive bibliography, see esp.: García GOMEZ (1944).

67 Without presenting his career in detail, suffice it to mention that apart from being a member of the Academia de Ciencias Morales y Políticas (1912), co-founder of the Centro de Estudios Históricos and of the journal »Cultura Española« (1906-1909), he was member of the Real Academia de la Lengua (1919), president and then, as of 1943, director of the Escuela de Estudios Árabes of Madrid and founder of the journal »Al-Andalus«, created in 1933.

68 Asín Palacios (1943).

69 Correspondences from Zaragoza, his city of birth.

70 Max Weber's indirect access to Islamic law and the fact that Goldziher was one of his main sources evidently raises many questions concerning the influence of Weber's sources on his perception and his theory on the Islamic legal culture.

71 June 22, 1850 in Stuhlweißenburg.

72 Goldziher was one of the rare Westerners to frequent the prestigious AlAzhar University in Cairo during 1873-1874. This fascination and res- pect seems to have been mutual: The Egyptian Shaykh deeply admired him for his knowledge and as for him, he did not hide his pride in being one of them, as his signature »The Hungarian of Al-Azhar" (al-Majari al-Azhari) is testament to. For more details and an account of the influence of Goldziher's thoughts on Weber, see: DJEDI (2007) $503 \mathrm{f}$. 
fiqh and Islamic theology on the one hand, and the design of an Islamische Rechtskultur (which includes aspects of popular life of Muslims ) conveyed by means of Sephardic Jewish culture from which he might have benefitted? Here lies a vast field of research that could enlighten about meetings and hybridization of the Muslim and Jewish medieval Spanish legal cultures and their infiltration in the history of European law through Jewish carriers, hidden Muslims, hidden Jews or converts to Christianity from both religions. ${ }^{73}$

Is it a coincidence, for example, that Goldziher was one of the foremost experts on the Zahiri school of law, that was especially highly developed in Al-Andalus, ${ }^{74}$ to the point that during the Sixth International Congress of Orientalists held in Leiden in 1883, and after reading an excerpt from his book Die Zabiriten, ${ }^{75}$ Shaykh Amin of Medina was so fascinated by Goldziher's knowledge that he declared him even a Shaykh of Islam? ${ }^{76}$ And is it a coincidence that Asín Palacios, a devout Christian, shows overlaps with Goldziher in his works on Ibn Hazm, the "carrier « of the Zahiri school of law in Al-Andalus, who later disappeared? ${ }^{77} \mathrm{Or}$ with Ibn Massarra and the origins of HispanoMuslim philosophy, ${ }^{\mathbf{7 8}}$ thereby realizing the desire expressed by Goldziher, who hoped for further study of this school in order to better understand and grasp controversies related to it?

Asín Palacios did not work directly on law. He was more of a mystic - marked by Muslim spirituality $^{79}$ - than a lawyer. A young student of Sufism, he »(...) thought himself to be something of a Sufi«. ${ }^{80}$ Yet his literary and mystical studies could certainly contribute significantly to the his- tory of Hispano-Islamic law. Why? For complex and intricate reasons. If it is true, indeed, that the most global resonance he received is that linked to his speech held on the occasion of his entry into the Real Academia Española: La escatología musulmana en la "Divina Comedia", ${ }^{\mathbf{8 1}}$ the importance of his reasoning, his assumptions so shocking and provocative to a Spain - and a Europe - that was defensive about everything that reminded it of its Islamic past, does not lie in the influence and exchange with Islam only; but also in new avenues opened to explore the normative universe of the Islamic past in Europe in a broad and multidimensional sense. By showing that Dante had used a text by Ibn Arabi to make his journey to the afterlife, he assumes the existence of a translation accessible to Dante (this would later be confirmed), ${ }^{\mathbf{8 2}}$ thereby opening an entire field of research. First, why did the theological, philosophical, literary and maybe legal Christian spirit voluntarily read, study, translated and become inspired by Islam just in order to abdicate the latter's culture, to deny it and wipe it out later? Secondly, what can these revelations like the discovery of new, previously inaccessible, untranslated or hidden texts - tell us about Islamic normativity, and particularly legal normativity?

This Islamic legal knowledge does not flow exclusively through the law. Poetry, literature, mysticism, songs, etc. all form valuable access points.

Between Dante and Ibn Arabi, but also all the rich literature on "al-Isra'wal Mi'raj « and the names that come up in the book by Asín Palacios such as Abul- 'ala Al- Maárri and many others, ${ }^{83}$ new knowledge of the logic of "monitoring and punishing in Islam emerges (see Figure 4). This Arabic
73 This is a serious hypothesis, yet one that deserves rigorous legal historical research to verify its veracity, as well as that of the influence or infiltration of the model of legal education represented by Muslim Madrasa in English law by means of converted Muslim carriers or Jews, as the latter also had their own form of Madrasa.

74 Zahirism is a literalist Sunni school of thought that emerged in the $9^{\text {th }}$ Century in Ispahan, Iran. It was founded by Dawud Ibn Ali Al-Asfahani $(815-884)$. From the $8^{\text {th }}$ Century, a theological and legal argument was in full swing in Islam between, on the one hand the people of the hadith (Sunna: second source of law) and the people of the opinion: the rationalists. On account of its literalism, the Zahiri school left no leeway to the judge, who could refer only to the Quran and the Sunna. Its greatest proponent and supporter in Al-Andalus was none other than the poet, philosopher, theologian and jurist Ibn Hazm Al-Andalusi of Córdoba.

75 GoldziHer (1884).

76 This formula expresses the highest formal recognition in Islamic »hierarchy«.

77 Asín Palacios (1907); Asín Palacios (1934); Asín Palacios (1939). See also: AdANG (2012).

78 Asín Palacios (1914); Asín Palacios (1992).
79 Much like many Westerners such as: Nallino, Massignon, Nicholson, Horten, Nyberg, Macdonald etc.

80 ARBERRY (1943) 61

81 In 1919.

82 We know today that there exists a Spanish version of »La Escala de Mahoma" dating back to the time of Alfonso X as well as two translations in Latin and French, cf. EcheVArría Arsuaga (2006) 173.

83 See the fascinating analysis by Asín Palacios: La Leyenda del viaje nocturno y ascensión de Mahoma cotejada con la »Divina Comedia«, Asín Palacios / Ribera (1919) $25 \mathrm{f}$. 
Fokus focus

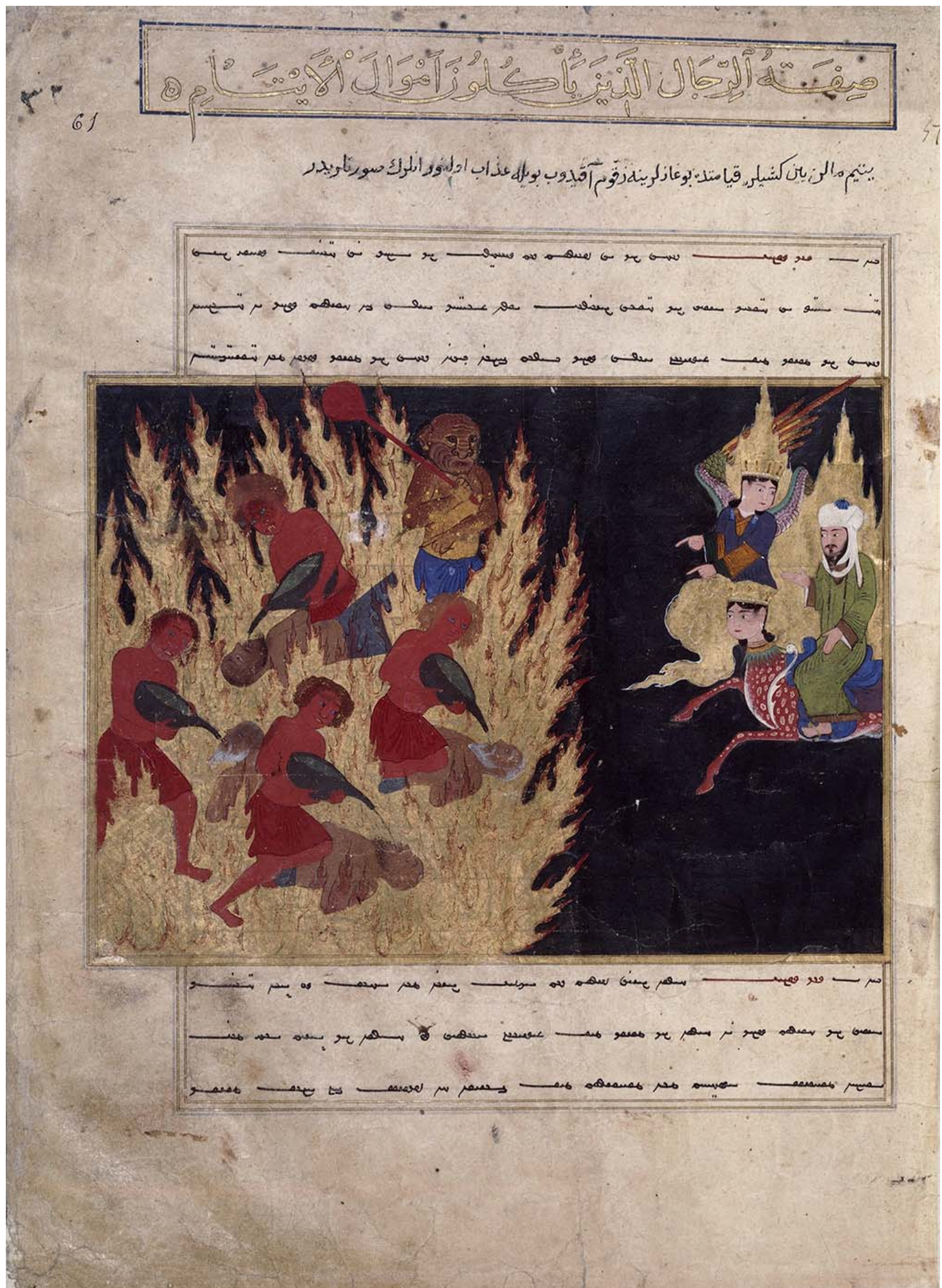

Figure 4: Farid al-Din Attâr de Neychâbour (1436): Le Livre de l'ascension du Prophète. Me'râdj-nâmeh. Mirâdj nâme, Copiste: Harou Malek Bakhchi $\odot$ Bibliothèque Nationale France 
literature, widely regarded today by the radical and sometimes even hard Islamists as blasphemous and dangerous books, should be reread and studied in the light of their own history, but also in the light of interaction with Europe. Al purgatorio islámico is not, in fact, only a matter for theology or literature, but also a deeply legal one. One need only compare fifteenth century engravings depicting the Prophet Muhammad on his buraq in hellin front of scenes of torture inflicted upon "sinners" and what, centuries later, certain Europeans (specifically French), left to wage jihad in Syria, drew on walls in Aleppo: scenes of divine punishment in hell! (See Figure 5)

Between Giovanni Boccaccio and the person who inspired him, his contemporary the mysterious Ali Al-Baghdadi, ${ }^{\mathbf{8 4}}$ storyteller at the Mamluk court in Egypt, the normative question is no stranger either. It is known today that the troubadours are indebted to the Arab courtly poetry that was passed on via Spain. The »Nouvelle occidentale aurait aussi profité à travers d'autres chemins de lecture et de diffusion, qui sillonnent une autre époque ${ }^{85}$ However, while the Western version was written for an elite, the Oriental one addressed a popular audience one with a work that, itself, drew on popular inspiration. This is yet another facet of Islam that emerges ... ${ }^{86}$

The mystique and jurist ${ }^{87}$ Ibn Arabi has developed another particular facet of Islam emerging in Andalusia. According to him, God as the »fundamentally Other « is a desire to reveal himself by way of the infinity of his names. In other words: if the human being is a divine creation, God is also a human creation through the response to the desire of knowing him. It is also him who has put forward mostly the analysis of love: a theory of love in front of the face of the other. ${ }^{\mathbf{8 8}}$ Remember the famous poem by Ibn Arabi:

My heart has become capable of every form: it is a pasture for gazelles and a convent for Christian monks,

and a temple for idols and the pilgrim's Kaa'ba, and the tables of the Torah and the book of the Quran.

I follow the religion of Love: whatever way Love's camels take,

love is my religion and my faith.

Furthermore, we still have to wait for the results of the analysis of recently discovered documents in Arabic language in the $16^{\text {th }}$ century (La Colección del Sacromonte del Archivo de la Real Chancillería de Granada) delivering important hitherto unknown information about a movement of religious syncretism among the moriscos under the threat of being expelled. ${ }^{\mathbf{9 9}}$

This type of interaction between theology, mysticism, philosophy, poetry, literature ... strikes us as exemplary for exchanges between the Islamic world and Europe that emerged from the $15^{\text {th }}$ Century on ...

$$
* * *
$$

Let us now approach the legal texts more directly. José López Ortiz (1989-1992) is considered the founder of »Spanish Arabism in its legal
84 For the record, the original manuscript of Baghdadi was ignored and forgotten for a few centuries. It had been related by mistake under a false cover page in the eighteenth century. The name of its real author was not known until after the false binding had been removed. In addition, the literary debate on the link of this work with Boccaccio is still open. See in this regard the introductory remarks by the editor and translator of Baghdadi: KHAwAM (1989).

85 Khawam (1989) 17.

86 A tolerant Islam that has no qualms in dealing with Christians and Jews, bon vivant, because - in imposing its law on the feminine element in particular - it tolerates wine, erotic dances and even an uninhibited female sexuality verging on libertinism.
87 Ibn Arabi has developed an interesting theory of legal pluralism in Islam ... However, his works have been attacked or marginalized by jurists and even Sufi scholars.

88 Jacques Lacan refers to Ibn Arabi in a famous conference in 1960, when he remembered the encounter Averroes and Ibn Arabi in Andalusia, saying that his proper standing as a psychoanalyst is more on this side of the mystical than that of the philosopher.

89 »El evidente trasfondo histórico está en su relación con uno de los acontecimientos históricos más importantes de la Granada del siglo XVI y que andando el tiempo afectaría a los reinos de la monarquía hispánica: la rebelión de los moriscos de la región de las Alpujarras entre 1568 y 1571 y su expulsión definitiva de los territorios de la corona española en 1609 . La abundante historiografía se ha ocupado extensamente de este tema en todos sus aspectos, y coincide en que este fraude, fraguado durante años, constituyó un audaz intento de sincretismo religioso y resistencia intelectual por parte de los moriscos granadinos a su expulsión; un desesperado intento por integrarse en la nueva sociedad cristiana que los Reyes Católicos habían proyectado para el recién conquistado reino de Granada. «I wish to express my thanks to David Torres, Director of the Archive of the Chancillería Real at Granada, for giving me the opportunity to see these documents in the process of restauration and providing background information on the collection. 


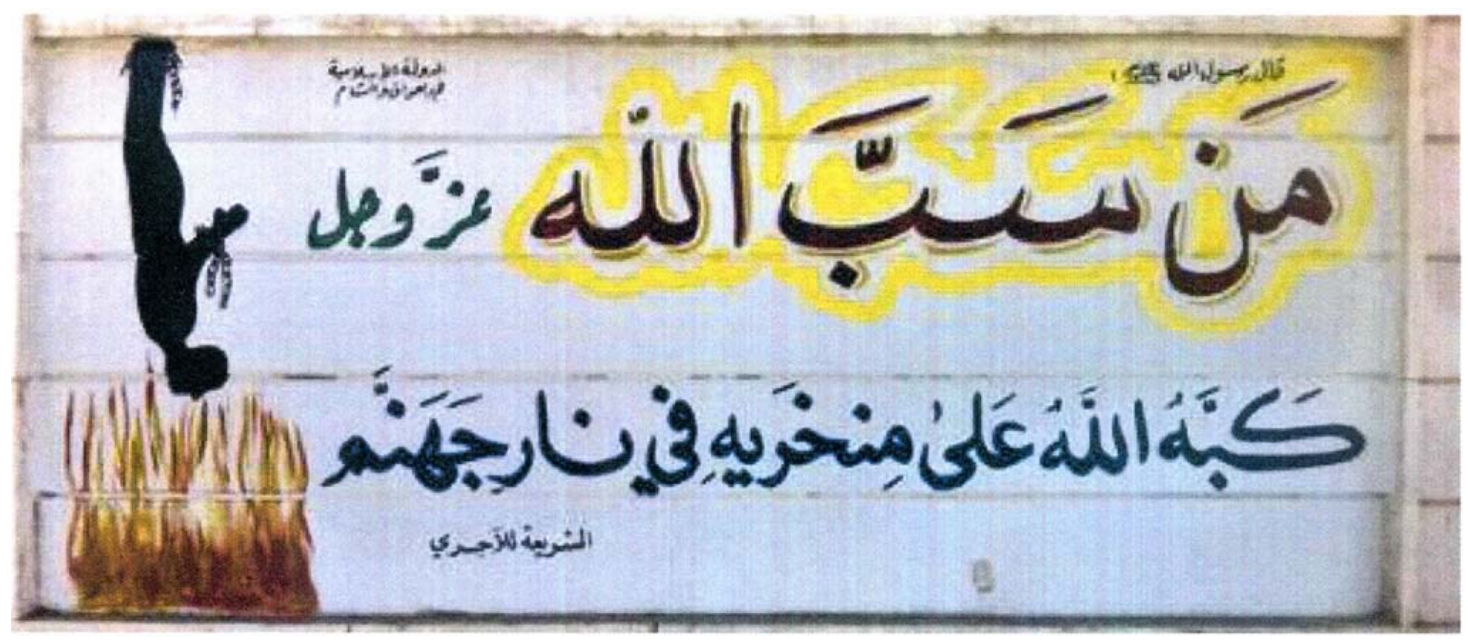

Figure 5: Graffiti in East Aleppo (2013/2014), a hadith attributed to the Prophet Muhammad, explaining the divine punishment for blasphemy: that is to be tortured with fire in hell @ France 24

dimension ${ }_{\circ}{ }^{90}$ Next to him, Salvador Vila, president of the University of Granada, published several fundamental works on institutional, notary (more on which below), matrimonial, etc. aspects of Spanish Islamic law in the $1930 \mathrm{~s}^{91}$ but also on German contributions to Arabism. ${ }^{92}$ The death of Ortiz and the premature passage of Vila put a break on this type of research to such an extent that Alfonso García-Gallo paints the picture of an orphaned Islamic law: »(...) el Derecho musulmán dejó de encontrar por entonces entre nosotros quienes se ocuparan de él». ${ }^{93}$ In fact, this claim needs to be somewhat relativized, as other researchers showed interest in the traces of Muslim lawyers in Andalusia and all of Spain, such as: Rafael Castejón Caldéron with his work Los juristas hispano-musulmanes $(1948)^{94}$ or La Historia de los jueces de Córdoba por Aljoxaní by Julían Ribera, which preceded it (1914). ${ }^{95}$ By and large, however, it was only as of the 1980s and particularly as of the 1990s and 2000s that "Muslim and Jewish elements«, as Gibert and de la Viga put it, were properly investigated in the history of Spanish law. ${ }^{96}$ To name but a few legal scholars engaging in such research: Bruno Aguilera Barchet, ${ }^{97}$ Magdelena Martínez Almira, ${ }^{98}$ Jesús Lalinde Abadía, ${ }^{99}$ etc.

Generally speaking, the recognition of two legal systems - a Muslim and religious one for Arabs and a civil one for Christians - dominates the discussions. Nevertheless, interferences and linkages between these normative universes have been proven through several studies including the following books: the work by Averroes on the legal sagacity of Arab Spain; Kitab al Qadi (book of the judge) on the history of judges in Cordoba; ${ }^{\mathbf{1 0 0}}$ Código de las Siete Partidas ${ }^{101}$ of king Alfonso $\mathrm{X}$ in which parts dedicated to legal rules applicable to Jews and Muslims showcase linkages and even what is commonly called an example of »conviviencia «; ${ }^{\mathbf{1 0 2}}$ and who could deny the crucial role of the Escuela de Traductores de Toledo? Numerous Arab manuscripts and books were translated into Latin and thereby transferred the essentials of Antique Greek and Roman heritage and - in the process - what the Islamic world was able to include, add, adapt and enrich. The nesting not only of knowledge and
90 »Arabismo español en su dimensión jurídica«, Martínez Dhier (2007a) 189.

91 Cf. for example: Vila (1933); Vila (1931). For fundamental reflections on the history of legal literature, see further: UREÑA Y SMENJAUd (1906a); Ureña y Smenjaud (1906b).

92 This particularly concerns the translation of the book by Adam Mez in
1936: El renacimiento del Islam. On his studies in Germany and his biography, see Амо (2005); MarTíneZ DHIER (2007b).

93 García-Gallo (1982).

94 Castejón Calderon (1948).

95 Ribera (1914).

96 Gibert/ De La Vega (1994).

97 Aguilera Barchet (2007). Cf. further Aguilera Barchet (1991).
98 Martínez Almira (1999).

99 Lalinde Abadía (1983).

100 IBN Rushd (1895).

101 Alfonso X/Real Academia de la Historia (1807).

102 The medieval concept of "convivencia « in Andalusia deserves a dedicated study. For a literary study, see: KRÜMMER (2005). 
cultures, but also of languages is fascinating. This has been demonstrated for Castilian with Arabic characteristics and vice versa, or also rabbinic Hebrew elements in Arabic ... ${ }^{103}$

Finally, and perhaps most importantly: they represent a type of text that bears witness to the documentary and historiographic complexity (and perhaps invisibility) of Muslim law in the historical landscape in general. This law of the Other suddenly becomes transparent, evaporates. Legally and sociologically, it sends us back to at least two extremely complex historical phenomena upon which to reflect.

The first, Las Leyes de Moros, is an anonymous $14^{\text {th }}$ Century manuscript written in Castilian and first published in 1853. ${ }^{\mathbf{1 0 4}}$ This famed text from the Real Academia de la Historia on the reception of Roman law in Spanish law is in reality but a partial reprise and summary of the Maliki treatise on jurisprudence Kitab al-Tafri by Ibn Al-Gallab. We have this knowledge thanks to studies conducted by several Spanish scholars starting in the 1990s that confronted the different versions of the Leyes de Moros with the Arabic text by Ibn AlGallab, such as the studies by: Alfonso Carmona González, ${ }^{105}$ Alvaro Galmés de Fuentes, Soha Abboud Haggar. ${ }^{106}$ They were actually preceded by the historian Eduardo de Hinojosa y Naveros who already underscored the influence of Roman law in the construction of the private law of Spanish Muslims in an 1885 article entitled »La introducción del studio del derecho romano en Castilla«. ${ }^{107}$ Without delving into the complex details of this manuscript, it is easy to see how the circulation of Roman law and Muslim law was fluid and permeable. ${ }^{108}$ Naturally, many questions on the interference, influence and overlap of these legal systems arise. On the European side, the reluctance and lack of specific knowledge - including among Romanist lawyers - is the dominant impression. The Arabo-Muslims, in turn, denounce such an idea for lack of knowledge ampli- fied by cultural narcissism. In any case, some proclaim, if one of the systems influenced the other, it can only be the Muslim one! ${ }^{109}$

Regarding the interferences and late reception in different European systems - including the Spanish one - the question does not only concern lawyers. One should recall that, particularly in the case of Spain, the historical controversy between Américo Castro and Claudio Sánchez Albornoz on the role of Arab culture in Spain remains relevant today. Albornoz wrote on La España musulmana según los autores islamistas y cristianos medievales (Buenos Aires, 1946). But it is particularly his work España, un enigma histórico published in two volumes in Buenos Aires (1956) where he defends his thesis of the continuity between Visigoth Spain, Christian Spain and Arab Spain. Castro, on the other hand, defends his thesis of complete rupture in his book España en su historia: cristianos, moros y judios (Buenos Aires, 1948). This chapter, which moves the discussion to Latin America, is certainly of exceptional importance in that it does not only touch upon the Islamic past in Spain, but also upon the historical and identitary implications in Latin America itself: this deserves in-depth study in itself.

The second phenomenon, El Breviario sunni in Segovia written in 1462 tells of a complex process during which the social body of the Other - as concerns the bias of his law - adapts, morphs or dissolves into the social landscape in general. Let us not forget the historical context of the period in question.

Around 1578, Muslims disappeared completely from Portugal (much like Jews, incidentally). From 1536, the inquisition hunted hidden Jews, hidden Muslims and Muslims. Records of their trials ${ }^{\mathbf{1 1 0}}$ show that these Muslims who converted to Christianity did not take communion, had trouble understanding the prayers, yet were not Muslims either. They were mostly identified by their practice of endogamy (a bad sign for integra-
103 On the importance of the Toledo school and the mingling and mixing of languages, see González PAlencia (1929), esp. $171 \mathrm{f}$.

104 Gebir/Real Academia de La Historia (1853).

105 See e. g.: Carmona González (1994); Carmona González (1993); Abboud Haggar (1997).

106 Abboud Haggar (1997).
107 Hinojosa y Naveros (1885) $320 \mathrm{f}$.

108 The question of dating is central to this type of research. See for example: Vespertino Rodriguez (19871989).

109 For this sentiment, see AbDEL-AL (1991) 90 f. However, specialists such as W. Hallaq, Makdisi, Vesey-Fitzgerald and others have dealt with this issue in a more differentiated way.
General studies, however, remain few and available studies in Arabic are exceedingly rare.

110 These archives are increasingly minutely studied by historians and incidentally also expose Spain to the richness of information they deliver on that period. 
Fokus focus

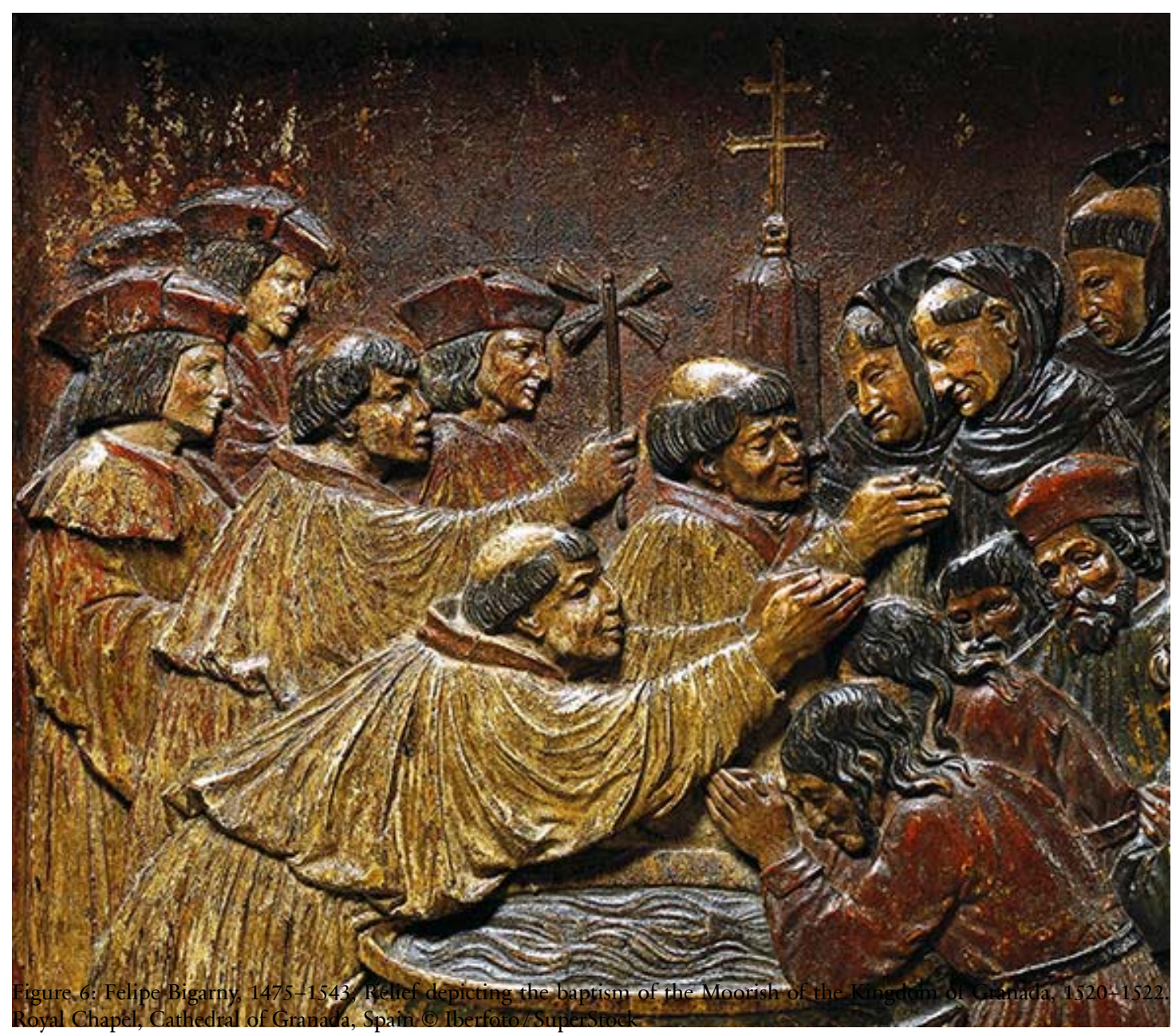

tion), by having one evening meal or by speaking Arabic. Unlike in Spain, Islamic law ceased to play any role. As for the Muslims chased out of Portugal, they travelled towards Castile from where their descendants would eventually also be expelled.

In Spain, Islamic law played an unprecedented and major role. Andalusia remained Muslim until 1492 and from the conquest in the $8^{\text {th }}$ Century until then, Muslims were able to develop an essentially Maliki legal system ${ }^{\mathbf{1 1 1}}$ which was unique in the entire Arabo-Islamic world ${ }^{\mathbf{1 1 2}}$ and featured a highly developed judicial organization. ${ }^{\mathbf{1 1 3}}$ While Muslims, Jews and Christians did coexist, their relationship became tense at the end of the $15^{\text {th }}$ Century, and all too often ended in forced conversion to Christianity (see Figure 6). This was followed by the first deportations following the Alpujarras revolt (1568-1571) and ended in depor-
111 Other legal schools were influenced by Malikism, but with a much more limited impact. This is the case with the Shafii and Zahiri legal systems, for example.

112 The originality of Spanish Malikism is linked to major efforts made by Andalusian Maliki lawyers and judges, on the one hand, and also has histor- ical, theological and sociological reasons which cannot be discussed indepth here due to their complexity. Incidentally, there is abundant literature on this subject. See, for example: LóPEZ-ORTIZ (1930), (1927) and (1931); Cano Ávila (1988) and (1995); Al-Habīi Al-Hĩla (2002); BŪ-LaŢīF (2009).
113 Müller (1999); Peláez Portales (2000) and (1999); Ribera (1914); Mendizabal Allende (1970); LópezORTIZ (1932). 
tation and definitive expulsion of los Moriscos between 1609 and 1614. The Christian Reconquista, whose main phase occurred in the $12^{\text {th }}$ and $13^{\text {th }}$ Century, led to the assimilation of the Muslim population ${ }^{114}$ through the majority Christian society. Muslims formed mudéjar communities that theoretically maintained their institutions in accordance with the terms of surrender. Except that integration into Christian society for those who so chose came at the price of conversion or abandoning the Arabic language. These thousands and hundred thousands of "new Moorish Christians", to distinguish them from the conversos, the Christians of Jewish origins, evaporated, they became transparent or invisible.

Their traces and faces are lost. Those who maintained a communal structure "formed morerías, separate quarters in cities, both large and modest, such as Avila, Burgos, Segovia, Valladolid, etc. The morerías kept their judges (qadis), their juries, their municipal and religious personnel ${ }^{\mathbf{1 1 5}}$ But in reality, they were subject to discriminatory treatment: »certains métiers leur sont interdits. Ils sont censés porter un signe distinctif, obligation qui n'est pas toujours respectée. Les vêtements de luxe leur sont également interdits «. ${ }^{\mathbf{1 1 6}}$ Later, once the waves of forced conversions broke starting in 1500, the alfaquís, legal and religious dignitaries were outlawed. Butchers, midwives, circumcision, the use of Arabic, the giving of Arab names and even jewelry and baths suffered the same fate. The battle over the female headscarf or public and private spaces was also in full swing. The headscarf would be forbidden and converted Muslims, under constant suspicion, had to leave the doors to their homes open to verify their loyalty. ${ }^{\mathbf{1 1 7}}$

In the midst of this tense atmosphere, and even starting somewhat before that, a new type of Islamic legal literature emerged to serve as a bridge, a passageway between two religions, two social groups and two normative universes. From then on - much like the almost parallel, yet different route taken by the Jewish community with the "tagganot « from 1432 - Islamic law sought to restore the Muslim community's socio-legal position, which had greatly suffered - again, much like the Jewish one - from forced conversions. Cultural disarray can detect social plasticity and mimetic stress where renunciation of difference moves the momentum towards law which becomes a place of exile, permeability and construction of a doublesided face, and an identity caught in the middle that is supposed to hold two sets of keys to two cultures.

For instance, in Segovia, Issa ben Gebir, the great al faqi and mufti of the mosque was asked to draft the Breviario Sunni in 1462. In his introductory remarks, the author highlights the cultural and legal problem faced by morerías who were no longer able to read Arabic and had lost their traditional education. He had been asked to write a short book in literary Spanish that was short and easy to read by all with no room for excuses. ${ }^{\mathbf{1 1 8}}$ Legal and religious topics were thus presented in a literary style previously unseen in Islamic law. Besides the genre or medium of communicating legal rules, it is especially the overlap and linkage of different normative orders that draws attention. The absorption of the Muslim normative order with others (Jewish or Christian) and vice versa becomes more fluid and hard to ascertain, as the borders become hard to trace and the normative picture is blurred. This type of compilation is not unique, as reference to the famous Tuhfa (the jewel) by Ibn Acem reveals. ${ }^{119}$ A wonderful compendium of Maliki law composed in the form of poems in which legal rules that achieve a high level of abstraction become easy to integrate in different legal systems. Moreover, the originality of the Tuhfa certainly lies in its at times "humorous« legal style married to a hint of feminism when it comes to rules of evidence of ownership of property belonging to the husband in case of separation for example. ${ }^{120}$ To laugh and make law in Islam was
114 For a unique case of assimilation, see: 116 Ibid. García Pedraza (1995).

$115 »(\ldots)$ forment les morerías, quartiers séparés dans les villes, grandes ou modestes, telles qu'Avila, Burgos, Segovia, Valladolid, etc. Les morerías conservent leurs juges (les cadis), leurs jurés, leur personnel municipal et religieuX«, VALENSI (2012) 23.
117 On this dark chapter of Spanish history, see for example: GarcíaArenal (2009); Vincent (2010); DomingueZ-OrTiz/Vincent (1978); Dadson (2007). One must recall that the relations between Muslims and Gypsies that featured mutually enriching interactions between the $14^{\text {th }}$ and $15^{\text {th }}$ Centuries is often kept silent, without forgetting the terrible persecution which the Gypsies suffered. Cf.: Martínez Dhier (2010).

118 Wiegers (1994) $125 \mathrm{f}$.

119 Houdas / Martel (1882).

120 Cf. the Arabic version IbN AсEm (n.d.) 28. 
Fokus focus

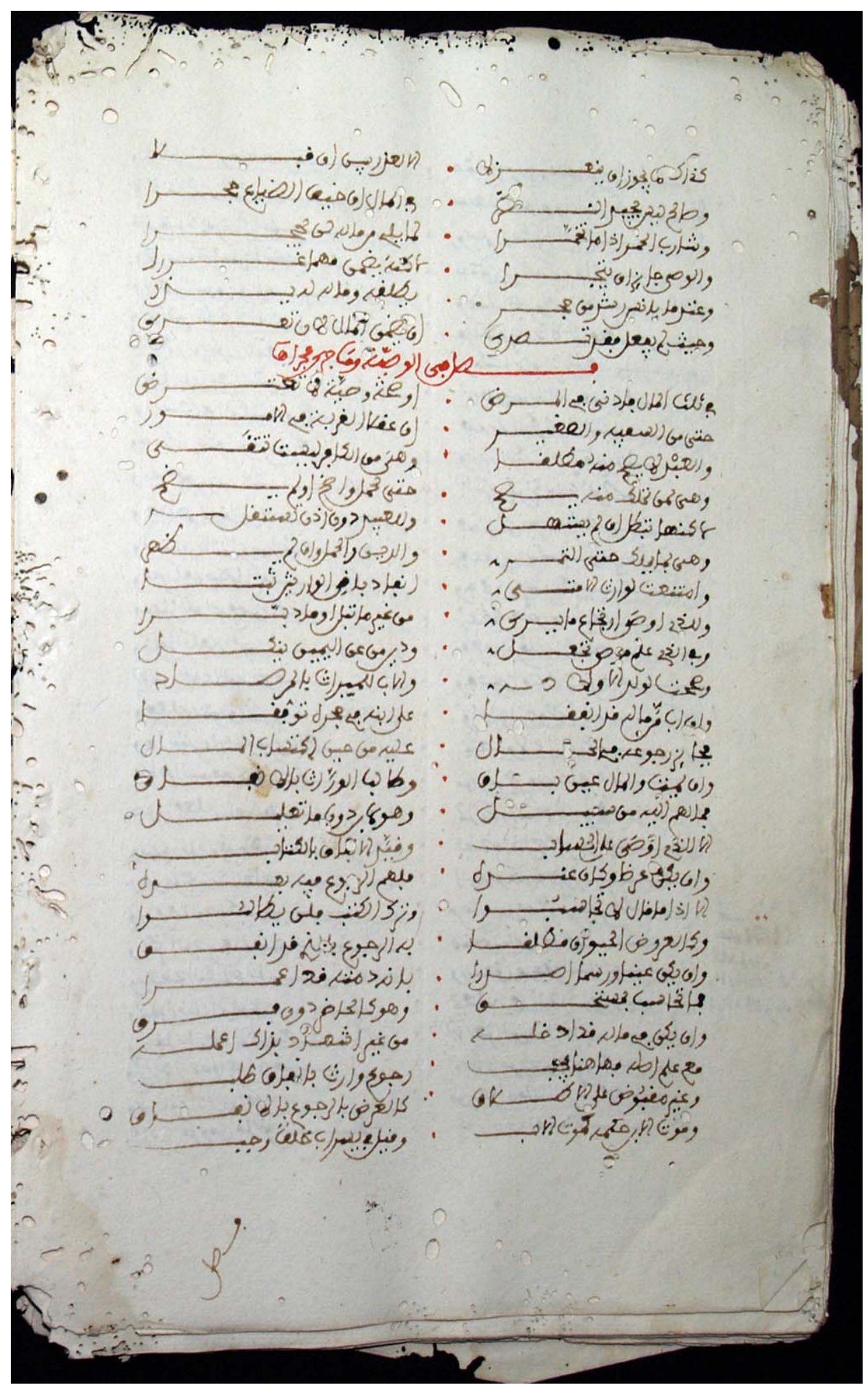

Figure 7: Ibn Asim de Granada, Tuhfat al-hukkam, El tesoro de los jueces. Adquirido en Tetuán, siglo XV, Códice de Tetuán, $\mathrm{n}^{\circ}$ XXXIV-1 @Fundación El legado andalusí/Biblioteca Municipal Central de Córdoba 
also one of the particularities of the Islamic law of Al-Andalus, as can even be seen in the title of the original Arabic version: Matn al-Asimiya al-musama bi-Tubfat al-Hukam fi nukati al'ukudi wal-abkam 'ala madhhab al-imam Malik ..., "nukati al'ukudi walabkam « meaning literally jokes of contracts and legal verses. ${ }^{\mathbf{1 2 1}}$ (See Figure 7)

Assuming an Islamic past with all the consequences that flow from it - both at the legal and at the social level - has largely passed by the Spanish context. Historians and theologians took the debates into account and all of Europe is affected. In this regard, the debates from the 1950s and 60s are of particular interest.

For historians of Spanish law, the work remains to be done, as this field of research remains largely unexplored. In his preface to the new edition of his book on the history of Muslim Spain, Lévi-Provençal remarks that the classic work by Dutch author Reinhardt Dozy, published in 1861, stops at the conquest of Andalusia at the beginning of the $12^{\text {th }}$ Century. On the morisques, there were "a few chapters « ${ }^{\mathbf{1 2 2}}$ barely disseminated (according to Lévi-Provençal) in one of the grand monographs by Altamira and de Bellesteros. ${ }^{123}$ In actuality, the coverage of Islamic history, let alone Islamic law, in the writings of Rafael Altamira is very minor. In his 1903 book Historia del derecho español, for example, Muslims and Jews are mentioned in passing in a chapter entitled "La costumbre en la historia del derecho español . In a very vague manner, Altamira mentions the formation of "new customs " that flowed from the special circumstances of these times and from »the typical cantonalism of medieval life and from contact with Muslims, Jews and European people who had come to Spain «. ${ }^{\mathbf{1 2 4}}$ Historically, an "estimable « ${ }^{\mathbf{1 2 5}}$ excessively hasty review was conducted by González Palencia in his short book Historia de la España musulmana. ${ }^{\mathbf{1 2 6}}$ However, the merit of clarifying translations, borrowing or mimicry is indisputable. Positions within the Muslim judicial organization morphed in the context of different Spanish institutions: sabib al-madina, whom one could call the civil governor, became prefecto de la ciudad, an almost literal translation; sahib al-xorta became prefecto de la guardia and even sabib al-leyl (what in Arabic literally means: the friend of the night, or he who accompanies the night), would become prefecto de la guardia nocturna. These positions that had been painstakingly institutionalized in southern cities such as Córdoba and Azzahra would be transposed to Christian cities after the Reconquista: to Zaragoza, Toledo and others. ${ }^{127}$ Particularly during the $12^{\text {th }}$ and $13^{\text {th }}$ Centuries and in several cities such as Aragon, Toledo, Seville or Murcia, the function of alcadi (literally judge in Arabic) was inseparable from the title of vizir ${ }^{\mathbf{1 2 8}}$ (wazir in Arabic), i.e. minister. This function which held the highest social representative role would be imitated by Christians, as Palencia points out, and gradually transferred to that of alcalde, or mayor. Further, the word alcalde is not far removed from that of the judge-minister, alcadi. In some instances, the imitation simply consisted in translating the name of the function: jurado (sworn juror) is the translation of almohtalef or almohalef in Arabic, maestro de la seca corresponds to sabebaceca (ceca is Arabic for money). Nevertheless, the most important of all positions derived from Muslims is, according to the author: "la justicia mayor de Aragon copiado del Sahebalmazalim (juez de las injusticias - literally the judge of injustices) que existía en el imperio de los Califas «. ${ }^{\mathbf{1 2 9}}$

This article does not aim at showcasing the influence of doctrines and legal institutions that can be traced back to Islamic traditions (especially, but not only in commercial law). This difficult analysis of legal transfer and subjacent reception has to be left for another occasion! Let me evoke only one example: contracts among Christians and Muslims about the selling of lands and houses formulated in Arabic terms and explicitly in conformity to Islamic law and remaining valid after the Reconquista of Granada. ${ }^{130}$ (See Figures 8.1-8.2)
121 IbN ACEM (n. d.) 9.

122 LÉvi-Provencal (1950).

$123 »(\mathrm{D})$ isséminés (selon les termes de Lévi Provençal) dans l'une ou l'autre des grandes monographies d'Altamira et de Bellesteros", ibid.

$124 »(. .$.$) del cantonalismo típico de la$ vida medieval, ya del contacto con los musulmanes, judíos y gentes europeas que venían a España «, Altamira (1903) 87.

125 Term used by Lévi-Provencal (1950).

126 González Palencia (1929).

127 González Palencia (1929) 197.

128 Ibid. 198.
129 Ibid. 199.

30 Documentos Árabes del Archivo Municipal de Granada (1481-1499). Sales contract between Muslim siblings and a Christian, 26. Chaaban 904 (8. April 1499). 
Historians like Richard Konetzke of Cologne, defend the thesis of a medium between Sánchez Albornoz and Castro. Such was the case during a major conference which was held in Cologne in 1957 under the title »Orient and Occident. The current state of large medievalist collections«. Such a thesis does not provide, however, any answers concerning the influence of Islamic law and Spanish law. Konetzke's distinction between the theory of the Quran and different practices of Spanish Muslims remains very ambiguous ${ }^{\mathbf{1 3 1}}$ and according to him the Reconquista could be ascribed only to a war of religions. ${ }^{132}$ Further, there is a big problem for the Catholic Church: the Inquisition. How many Protestant, Muslim, Jewish and indigenous victims were there? This not only concerns the moriscos in Spain, as one should not forget the indigenous population of Latin America who were massacred on a large scale across an entire continent. The book Historia de la inquisición en España y América, published in 1993, ${ }^{\mathbf{1 3 3}}$ indicates parallels that have yet to be further developed and researched. In Spain, the Inquisition brought about the "pedagogía del miedo" (pedagogy of fear) or forced conversion. Then there was the statute on the "limpieza de sangre" (purity of blood) that, in the $16^{\text {th }}$ Century, forbade moriscos from physically mixing with »old Christians", they were excluded from »a great number of institutions: civic, religious as well as colleges and universities «. ${ }^{134}$ Even worse, this statute prohibited old Christians from having sexual relations with individuals whose ancestry did not conform to theirs. In a recent study published in 2009 entitled Deportados en nombre de Dios. La expulsión de los moriscos ..., Raphael Carrasco insists on an overwhelming reality: the exclusion of moriscos from a large number of academic, civic and religious institutions. These statutes, he claims, were not a response to a deliberate royal policy, but to a social demand by ordinary Spaniards. ${ }^{135}$ Excluded, harassed, suspected and persecuted by the Inquisition, one group became increasingly foreign to the other. Identities mingled, were transformed and broken. Hundreds of thousands of beings ${ }^{\mathbf{1 3 6}}$ became invis- ible or evaporated with their bodies and souls, their old and new religions and their at times Islamic identities.

We all know about later episodes of such a scary process in Europe in the 1930s and 40s. Did Christian Spain really mirror the effects of the dhimmi status - developed by Muslims for nonMuslims in Islamic territories - and apply them to moriscos or to the indigenous population in South America? Why did such a religious and legal statute result in a cruel exclusion of the Other? It is true that the outdated concept of dhimmi in Islamic territory did not escape a perverse functionalization through those in power in times of tension or war. This, perhaps, points to the universal character of the problem: the Other is often perceived as a nuisance and someone unbearable, to one as to the other. But the Other is at the same time necessary for the process of distinction.

The history of entangled legal culture demarcates the invisible line between the interior and the exterior. This article is not meant to explain the question where this lack of memory about the boundary definition of the other by way of legal otherness in European History comes from. From the Balkans to the Mediterranean area, Sicily, Southern France, Al-Andalus and even to Britain, a subjacent trace of Islamic cultures with specific normative traditions delivered a folio from which »Europeanness" was to be distinguished. Insofar, the excluded have become part of the story of European identity. But this story has still to be told as a rather complex narrative.

\section{Conclusion}

Europa hat sich immer nur gegen etwas, nie für etwas zusammenschließen können. Europa erlebt seine Einheit vor allem dann, wenn es um die Abwehr einer gemeinsamen, gedachten oder wirklichen Gefahr geht, und es verliert diese Einheit, wenn die Gefahr verschwunden ist. $^{137}$
131 KonetzKe (1971).

132 Ibid. 226.

133 Perez Villanueva / Escandell BONET (1993).

134 Valensi (2012) 26.
135 Carrasco (2009) 42-56, this debate still remains open, of course.

136 Raphael Carrasco claims a figure of 200,000 new-Christians who, in the middle of the $16^{\text {th }}$ Century, fled to
Italy, the Balkans or France or left for Africa, Carrasco (2009) 288.

137 Schulze (1995) 327. 
(4)

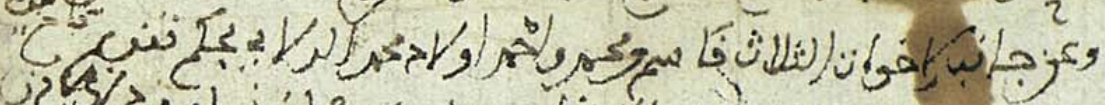
i) (13) $>$ s 3 is

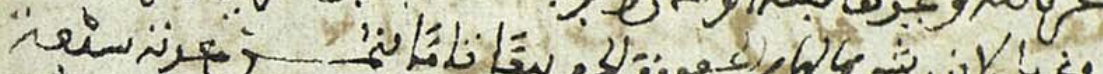
Gil f

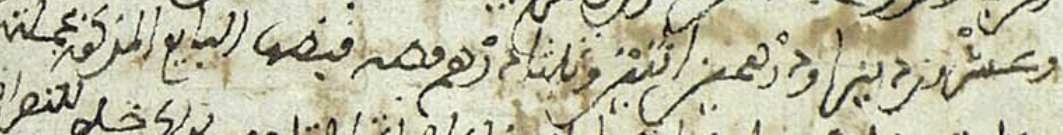

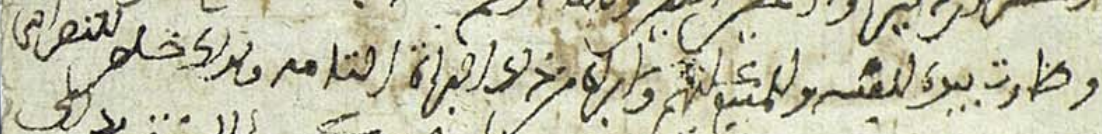
5)

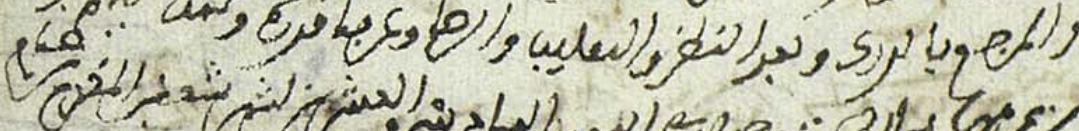

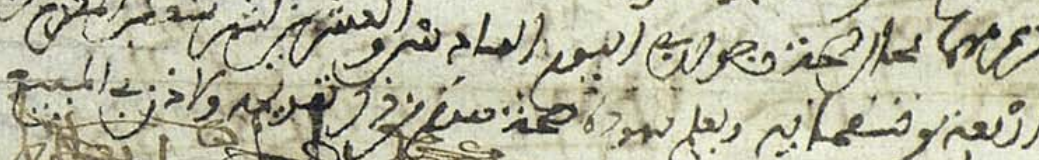
a 1 - की

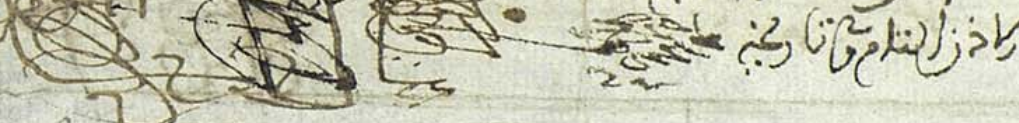

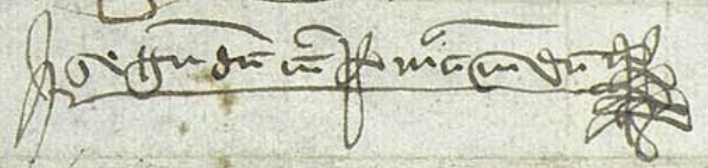

4
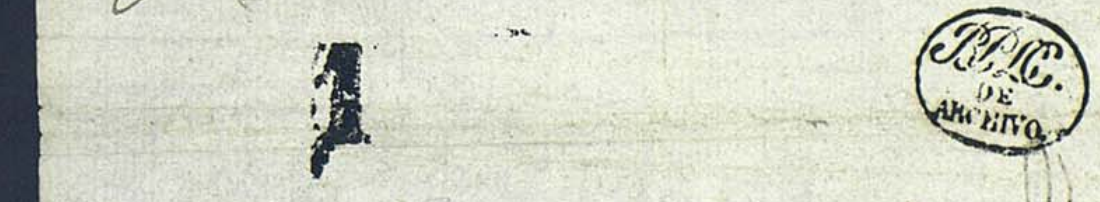

para

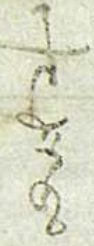

Figures 8.1 + 8.2: Sales contract between Muslim siblings and a Christian, Chabaan 26, 904 (April 8 1499), Documentos Árabes del Archivo Municipal de Granada (1481-1499) () Archivo Municipal de Granada 


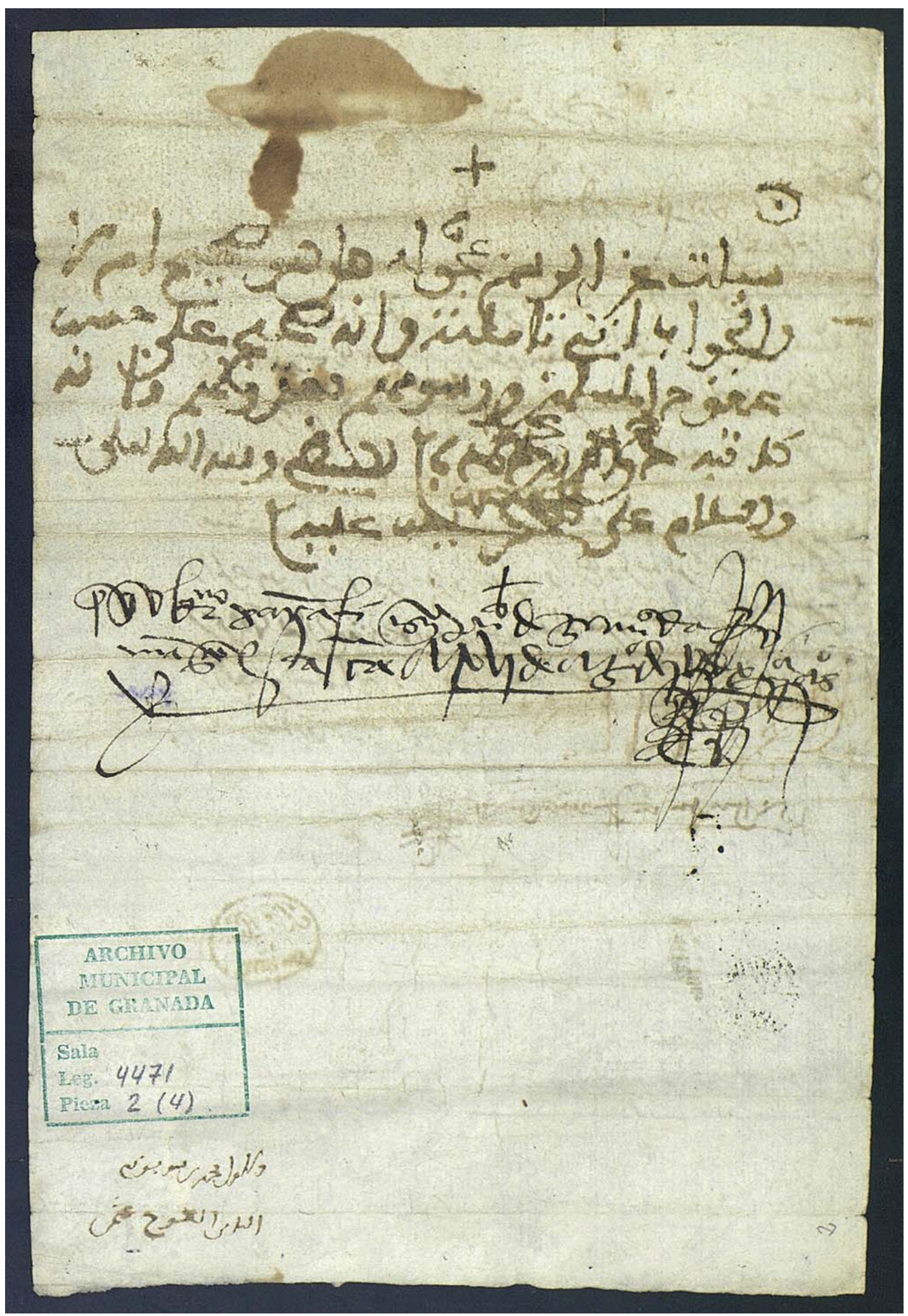


But Europe is not only exclusion, expulsion and inquisition. It is also the cradle of the fascination for the Other. It is the travels and wanderlust of Goethe in the welcoming and marvelous world of the West-östlicher Divan. It is Orientalism and the explosion of dazzling colors and lights from India and China. To take into account the history of the Other and a shared past on European ground is ultimately to take into account the possibility of the same, i.e. of communality, to activate a situation in which modes of cohabitation, mutual knowledge and concrete experimentation with the Other are invented.

The case of Islam and Islamic law is emblematic for Europe, not only for historical reasons, but also very contemporary and complex ones. One need merely point to problems with integration, with global and transnational Islam and troubling or even dangerous phenomena that have been occurring. One need merely look at the propaganda from an Islamic minority jurisprudence that locks itself in, is bitter and uprooted; or one might take note of claims for the institution of a concept of Sharia that has nothing to do with Islamic law as a legal system; or, finally, one might focus on the vertiginous process of a new Islamic fascism that is propagated by some both within post-revolutionary Arab countries and in the world at large. However, the dynamic of ruptures and innovations does not preclude any cultural difference or pluralism. Europe is not alone in having to face its own history: what did India and the Hindi make of their Mughal history?

Collective memory is shaped and selective, identity politics may prescribe oblivion of the Other, ${ }^{138}$ but historiography is not meant to deny historical facts that sometimes must be brought back to the surface of our consciousness.

\section{Bibliography}

- Abboud Haggar, Soha (1997), Las Leyes de Moros son el libro de Al-Tafri, in: Cuadernos de Historia del Derecho 4, 163-201

- Abdel-Al, UQAcha Mohamed (1991), Tarikh al-muassassat al-ijtimai'ya wal qanuniya wal qanun al-rumani, Beyrouth: nachr addar al-jami'ya

- Adang, Camilla (2012), Ibn Hazm of Cordoba. The Life and Works of a Controversial Thinker, Leiden: Brill

- Agamben, Giorgio (2003), Was von Auschwitz bleibt. Das Archiv und der Zeuge. Homo Sacer III, Frankfurt am Main: Suhrkamp

- Agius, Dionisius A., Richard Hitchcock (eds.) (1994), The Arab influence in Medieval Europe, Reading: Ithaka Press

- Aguilera Barchet, Bruno (1991), Reflexiones sobre el concepto de Historia del Derecho, in: Anuario de la Facultad de Derecho de Cáceres 9, 297-378

- Aguilera Barchet, Bruno (2007), Iniciación histórica al Derecho Musulmán, Madrid: Dykinson

- Alfonso X/Real Academia de la Historia (1807), Las siete Partidas de Alfonso X el Sabio, last retrieved May 182014 from: http://bibliotecadigital.rah.es/dgbrah/es/consulta/registro.cmd?id=44594

- Al-Habīb Al-Hīla, Munammed (2002), Fatāwā al-Burzulī: ğāmi ' masā’ il al-aḥkām li-mā nazala min al-qaḍāyā bi-'1-muftīn wa-'1ḥukkām, Bairūt: Dār al-Ġarb al-Islāmī

- Almeida Mendes, António De (2011), Musulmans et mouriscos du Portugal au XVIe siècle, in: DaKhlia/Vincent (2011) 143-158

- Alonso Acero, Beatriz (2006), Sultanes de Berbería en tierras de la cristiandad. Exilio musulmán, conversión y asimilación en la Monarquía hispánica (siglos XVI y XVII), Barcelona: Bellaterra

- Altamira, Rafael (1903), Historia del derecho español, Madrid: Suárez

- Alland, Denise, Stéphane Rials (2007), Personne, in: Dictionnaire de la Culture juridique, Paris: PUF

- Amo, Mercedes Del (2005), Salvador Vila, el Rector fusilado en Víznar, Granada: Editorial Universidad De Granada

- Angiolini, Franco (1997), Slaves and slavery in Early Modern Tuscany, in: Italian History and Culture 3, 67-86

- Aquinas, Thomas (1270), De unitate intellectus contra Averroistas, translated as: On the Uniqueness of Intellect Against Averroes, last retrieved on May 132014 from: http://dhspriory.org/thomas/english/DeUnitateIntellectus.htm

138 As González García (2008) has argued in his article about the Franco period, law can take over the role of remembrance. 
- Arberry, Arthur John (1943), An Introduction to the History of Sufism. The Sir Abdullah Suhrawardi Lectures for 1942, London: Longmans, Green and Company

- Asad, Muhammad, Hans Zbinden (eds.) (1960), Islam und Abendland. Begegnung zweier Welten, Olten: Walter

- Asín Palacios, Miguel (1907), La indiferencia religiosa en la España musulmana según Abenhazam, Madrid: Impr. Ibérica

- Asín Palacios, Miguel (1914), Abenmasarra y su escuela. Orígenes de la filosofía hispanomusulmana, discurso leído en el acto de su recepción, Madrid: Impr. Ibérica

- Asín Palacios, Miguel (1934), Un códice inexplorado del cordobés Ibn Hazm, in: Al-Andalus 2,1, 1-56

- Asín Palacios, Miguel (1939), El origen del lenguaje y problemas conexos en Algazel, Ibn Sida e Ibn Hazm, in: Al-Andalus 4,2, 253-281

- Asín Palacios, Miguel (1940), Contribución a la Toponimia Árabe de España, Publicaciones de las escuelas de estudios árabes de Madrid y Granada, Madrid

- Asín Palacios, Miguel (1941), El Averroismo teológico de Santo Tomás de Aquino, in: Huellas del Islam. Sto. Tomás de Aquino, Turmeda, Pascal, S. Juan de la Cruz, Madrid: Espasa-Calpe, 15-72

- Asín Palacios, Miguel (1943), Glosario de voces romances registradas por un botánico anónimo hispanomusulman (siglos XI XII), Madrid: Escuela de Estudios Árabes de Madrid y Granada

- Asín Palacios, Miguel (1992), Tres estudios sobre pensamiento y mística hispanomusulmanes. Ibn Masarra y su escuela, Madrid: Hiperión

- Asín Palacios, Miguel, Julian Ribera (1919), La Leyenda del viaje nocturno y ascensión de Mahoma cotejada con la »Divina Comedia«, in: La escatología musulmana en la Divina comedia, discurso Reído en el acto de su recepcíon, Madrid: Imprenta de Estanislao Maestre, 7-97

- Aymard, Maurice (1973), Chiourmes et galères dans la Méditerranée du XVIe siècle, in: Labrousse Ernest, Bartholomé Bennassar (eds.), Mélanges en l'honneur de Fernand Braudel. Histoire économique du monde, Vol. I, Toulouse: Privat, 49-64

- Baudelaire, Charles (2001), Mon cœur mis à nu, edited by Claude Pichois, Genève: Librairie Droz

- Benhabib, Seyla (2004), The Rights of Others. Aliens, Residents and Citizens, Cambridge: Cambridge University Press http:// dx.doi.org/10.1017/CBO9780511790799

- Bennassar, Bartolomé (1996), Conversions, esclavage et commerce des femmes dans les péninsules ibérique, italienne ou balkanique aux XVIe et XVIIe siècles, in: Dimensioni e problemi della ricerca storica 2, 101-109

- Bennassar, Bartolomé (2009), L'esclavage des femmes en Europe à l'époque moderne, in: Storia delle donne 5, 131-146

- Bennassar, Bartolomé, Lucile Bennassar (1989), Les Chrétiens d'Allah. L'histoire extraordinaire des renégats, XVI ${ }^{\mathrm{e}}$ et XVII siècles, Paris: Perrin

- Bennassar, Bartolomé, Robert Sauzet (1998), Chrétiens et musulmans à la Renaissance. Actes du $37^{\mathrm{e}}$ colloque international du CESR (1994), Paris: H. Champion

- Benslama, Fethi (2009), Psychoanalysis and the Challenge of Islam, translated by Robert Bononno, Minneapolis: University of Minnesota Press

- Bono, Salvatore (1998), Conversioni di musulmani al cristianesimo, in: Bennassar/Sauzet (1998) 429-445

- Bono, Salvatore (1999), Schiavi musulmani nell'Italia moderna. Galeotti, vu' cumpra', domestici, Univerita degli studi di Perugia

- Borja Medina, Francisco de (1988), La Compañía de Jesús y la minoría morisca (1545-1614), in: Archivum Historicum Societatis Iesu 57,113, 3-136

- Bousquet, Georges-Henri (1947), L'exploration juridique de l'Algérie et de l'Afrique du Nord (Droit musulman), in: B.E.A. 33, 99-105

- Bū-Lațīf, Lahdar Muhammad (2009), Fuqahā' al-mālikīya wa-'t-tağriba as-siyāsīya al-muwaḥhidīya fī 'l-g̣arb al-islāmī: (510668 h. / 1116-1269 m.), Herndon: al-Ma had al- 'Ālamī li-'l-Fikr al-Islāmī

- Cano Ávila, Pedro (1988), Sobre algunos maestros y contemporanes del Granadino Abul-Qasim Ibn Salmun, in: Miscelanea de Estudios árabes y hebraicos, vol. XXXVII, 37-55

- Cano Ávila, Pedro (1995), El contrato de compraventa con derecho de opción (bay'al-jiyar) y con derecho de recuperación (tunya), según el jurista granadino Ibn Salmun (siglo XIV), in: Concepción Vázquez De Benito, Maria De La, Miguel Ángel Manzano Rodríguez (eds.), Actas XVI Congreso UEAI, Consejo superior de Investigaciones Científicas, Salamanca, 89-99

- Cardini, Franco (2000), Europa und der Islam. Geschichte eines Mißverständnisses, translated by Rita Seuß, München: Beck

- Carmona González, Alfonso (1993), Consideraciones sobre la perviviencia de la jurisprudencia andalusí en las épocas mudéjar y morisca, Actas del V Congreso International para los estudios morisco-andalusí, Zagwan, 209-222

- Carmona González, Alfonso (1994), El autor de las Leyes de moros, Homenaje al profesor Fórneas Besteiro, vol. II, Granada: Universidad de Granada, 957-962

- Carrasco, Rafael (2009), Deportados en nombre de Dios. La expulsión de los moriscos: carto centenario de una ignominia, Barcelona: Destino

- Castejón Calderon, Rafael (1948), Los juristas hispano-musulmanes (Desde la conquista, hasta la caída del califato de Córdoba. Años 711 á 1031 d. C.), Madrid: Instituto de Estudios Africanos, Ediciones Ares

- Castro, Américo (1948), España en su historia: cristianos, moros y judíos, Buenos Aires: Losada

- Chebel, Malek (2006), L'islam et la Raison, Paris: Perrin

- Cleff, Wilhelm (1934), Die Weiße Trommel, Potsdam: Ludwig Voggenreiter

- Colombo, Emanuele (2011), Baldassare Loyola de Mandes (1631-1667), prince de Fez et jésuite, in: Dakhlia/Vincent (2011) 159-193

- Colley, Linda (2003), Captives. Britain, Empire and the World, 1600-1850, New York: Anchor Books

- Contat, Michel, Michel Rybalka (1973/1992), Jean Paul Sartre. Un Théâtre de situations, Paris: Gallimard 
- Copleston, Frederick (1954), A History of Philosophy II. Medieval Philosophy, Augustine to Scotus, London: Burn Oates \& Washbourne LTD

- Dadson, Revor J. (2007), Los Moriscos de Villarrubia de los Ojos (siglos XV-XVIII). Historia de una minoria asimilada, expulsada y reintegrada, Madrid: Iberoamericana

- Dakhlia, Jocelyne, Bernard Vincent (2011), Les Musulmans dans l'histoire de l'Europe. Une intégration invisible, Tome I, Paris: Albin-Michel

- Dakhlia, Jocelyne, Bernard Vincent (2013), Les Musulmans dans l'histoire de l'Europe. Passages et contacts en Méditerranée, Tome II, Paris: Albin-Michel

- DJedi, Youcef (2007), Max Weber et l'Islam, Thèse pour le doctorat en Philosophie, École Normale Supérieure - Lettres et Sciences Humaines, Lyon

- Dominguez Ortiz, Antonio, Bernard Vincent (1978), Historia de los Moriscos, vida y tragedia de una minoría, Madrid: Revista de Occidente

- Durkheim, Emile (1975), Lettre adressée à Gaston Richard en date de 1899, in: Karady, Victor (ed.), Émile Durkheim. Religion, morale, anomie, Textes (2), Paris: Les Éditions de Minuit

- Duve, Thomas (2012), Von der Europäischen Rechtsgeschichte zu einer Rechtsgeschichte Europas in globalhistorischer Perspektive, in: Rechtsgeschichte 20, 18-71, last retrieved on May 152014 from: http://data.rg.mpg.de/rechtsgeschichte/ rg20_018duve.pdf http://dx.doi.org/10.12946/rg20/018-071

- Echeverría Arsuaga, Ana (2006), La reescritura del Libro de la escala de Mahoma como polémica religiosa, in: Cahiers de linguistique hispanique médiévale 29, 173-199 http://dx.doi.org/10.3406/cehm.2006.1964

- El Alaoui, Youssef (2006), Jésuites, Morisques et Indiens. Étude comparative des méthodes d'évangélisation de la Compagnie de Jésus d'après les traités de José de Acosta (1588) et d'Ignacio de Las Casas (1605-1607), Paris: H. Champion

- El Baz, Salim Rostom (1988-89), Charh al'Majella. Rapport de présentation et d'analyse de la Madjella, Medjellé ottoman, traduction en Arabe commentée, 2 volumes, Beyrouth

- Fisher, Godfrey (1957), Barbary Legend. War, Trade and Piracy in North Africa, 1415-1830, Oxford: Clarendon Press

- García Gómez, Emilio (1944), Don Miguel Asín (1871-1944). Esquema de una biografía, in: Al-Andalus 9,2, 267-292

- García Pedraza, Amalia (1995), La Asimilación del Morisco Don Gonzalo Fernández El Zegrí. Edición y análysis de su testamento, in: Al-Qantara XVI,1, 39-58

- García-Arenal, Mercedes (2009), Religious Dissent and Minorities. The Morisco Age, in: The Journal of Modern History 81, 888-920 http://dx.doi.org/10.1086/605489

- García-Gallo, Alfonso (1982), Breve historia del Anuario, in: A.H.D.E. 51, 71-131

- Gebir, Don Ice De, Real Academia de Historia (1853), Tratados de legislación musulmana: 1. Leyes de moros del siglo XiV. 2. Suma de los principales mandamientos y devedamientos de la ley y çunna, Madrid: Real Academia de la Historia

- Gephart, Werner (1999), Zur sozialen Konstruktion europäischer Identität. Symbolische Defizite und europäische Realitäten, in: Gephart / SAURWEIN (1999) 143-168

- Gephart, Werner (ed.) (2012a), Rechtsanalyse als Kulturforschung, Schriftenreihe des Käte Hamburger Kollegs »Recht als Kultur», vol. 1, Frankfurt am Main: Vittorio Klostermann

- Gephart, Werner (2012b), Für eine geisteswissenschaftliche Erforschung von Recht im Globalisierungsprozess, in: Gephart (2012a) 19-53

- Gephart, Werner (forthcoming), The concept of validity culture. Conference held at the international conference "The Normative Complex. Legal Cultures, Validity Cultures, Normativities« 2014 in Bonn

- Gephart, Werner, Hans Waldenfels (eds.) (1999), Religion und Identität. Im Horizont des Pluralismus, Frankfurt am Main: Suhrkamp

- Gephart, Werner, Karl-Heinz Saurwein (eds.) (1999), Gebrochene Identitäten: Zur Kontroverse um kollektive Identitäten in Deutschland, Israel, Südafrika, Europa und im Identitätskampf der Kulturen, Opladen

- Gephart, Werner, Raja SaKrani (2012), »Recht« und »Geltungskultur«. Zur Präsenz islamischen Rechts in Deutschland und Frankreich, in: Gephart (ed.) (2012a) 103-137

- Gibert, Rafael, Sánchez de la Vega (1994), Los elementos musulmán y judío en el estudio jurídico español, in: Estudios de Historia del Derecho europeo, Homenaje al Profesor G. Martínez Díez, Volumen 3, Madrid: Editorial Complutense, 55-129

- Giesen, Bernhard (1999), Codes kollektiver Identität, in: Gephart / Waldenfels (1999) 13-43

- Goldziner, Ignác (1884), Die Zahiriten: ihr Lehrsystem und ihre Geschichte, Leipzig: Otto Schulze

- González García, José María (2008), Cultural Memories of the Expulsion of the Moriscos, in: European Review 16,1, 91-100

- González Palencia, Ángel (1929), Historia de la España musulmana, $2^{\text {nd }}$ ed., Barcelona: Editorial Labor

- Grossi, Paolo (2009), L'Europa del diritto, $9^{\text {th }}$ ed., Roma: Laterza

- Grousset, René (1934-1936), Histoire des croisades et du royaume franc de Jérusalem, 3 vol., Paris: Plon

- Hattenauer, Hans (2004), Europäische Rechtsgeschichte, $4^{\text {th }}$ ed., Heidelberg

- Hegri, Klára, Vera Zimányi (1988), Muslime und Christen. Das Osmanische Reich in Europa, Budapest: Franklin

- Hinojosa Y Naveros, Eduardo de (1885), La introducción del estudio del derecho romano en Castilla, in: Historia del Derecho romano, según las más recientes investigaciones III, Madrid: Imp. de la Revista de legislacíon

- Hitzel, Fréderic (2011), Turcs et Turqueries à la cour de Catherine de Médicis, in: Dakhlia/Vincent (2011) 33-54

- Houdas, Victor, Felix Martel (1882), Traité de Droit musulman. La »Tohfat d'IBN ACEM«, Texte arabe avec traduction francaise. Commentaire juridique et notes philologiques, Alger: Gavault T. Saint

- Iвn Aсем (n. d.), Matn al-Asimiya al-musama bi-Tuhfat al-Hukam fi nukati al'ukudi wal- ahkam 'ala madhhab al-imam Malik, Egypt: Al-Matba'a al-barunia

- Ibn Al-Athir (1231/1979), Al-Kamil fi al-Tarikh (The Perfect History), 13 vol., Beyrouth: Dar Sadir

- Ibn Al-Qalanissi (1908), Zayl Tarikh Dimachq (History of Damascus), Arabic version, Damascus 
- IbN Rushd (1895), Kitab falsafat al-qadi al-fadil Ahmed Ibn Ahmend Ibn Rushd Al-Andalusi, Al-matba'a al-ilmiya

- InRAP (2013), Programme de la Conférence Héritages arabo-islamiques dans l'Europe méditerranéenne. Archéologie, histoire, anthropologie, Institut national de recherches archéologiques préventives (Inrap), last retrieved on May 152014 from: http:// www.inrap.fr/archeologie-preventive/Ressources/p-15712-Heritages-arabo-islamiques-en-Europe-mediterraneenne-Archeologie-histoire-anthropologie.htm

- Kaiser, Wolfgang (2011), Asymétries méditerranéennes. Présence et circulation de marchands entre Alger, Tunis et Marseille, in: DAKhlia/Vincent (2011) 417-442

- Kaiser, Wolfgang (2013), Zones de transit. Lieux, temps, modalités du rachat de captifs en Méditerranée, in: Dakhlia/ VinCENT (2013) 251-272

- Khawam, René (1989), Les fleurs éclatantes dans les baisers et l'accolement. Texte établi sur les manuscrits originaux, Paris: Phébus

- Kierkegaard, Søren (1849/2013), The Sickness unto Death, Kierkegaard's Writings, vol. 9, edited and translated by Howard V. Hong and Edna H. Hong, Princeton University Press

- Konetzke, Richard (1971), Probleme der Beziehungen zwischen Islam und Christentum im spanischen Mittelalter, in: Wilpert, Paul (ed.), Antike und Orient im Mittelalter: Vorträge der Kölner Mediaevistentagungen 1956-1959, Berlin: W. Gruyter, 219-238 http://dx.doi.org/10.1515/9783110876604.219

- Krümmer, Anne (2005), Fremd- und Selbstbilder in der spanischen Literatur des Mittelalters, Institutional Repository der Universität Konstanz, last retrieved on May 132014 from: http://nbn-resolving.de/urn:nbn:de:bsz:352-opus-16226

- Lalinde Abadía, Jesùs (1983), Iniciación Histórica al Derecho español, $3^{\text {rd }}$ ed., Barcelona

- Larqué, Claude (1998), Captifs chrétiens et esclaves musulmans au XVIIe siècle: une lecture comparative, in: Bennassar/ SAUZET (1998) 391-404

- Laurens, Henri, John Tolan, Gilles Veinstein (2009), L’Europe et l'islam. Quinze siècles d'histoire, Paris: Odide Jacob

- Levinas, Emmanuel (1982), Éthique et infini. Dialogues avec Philippe Nemo, Paris: Fayard

- Levinas, Emmanuel (2006), Totalité et infini. Essai sur l'extériorité, Paris

- Lévi-Provencal, Evariste (1950), Histoire de l'Espagne musulmane. Tome I, La conquête et l'émirat hispano-Umaiyade (710-912), $2^{\text {nd }}$ ed., Paris: Maisonneuve

- López-Ortiz, José (1927), Algunos capítulos del formulario notarial de Abensalmún de Granada, in: A.H.D.E. 4, 319-375

- López-Ortiz, José (1930), La recepción de la escuela maleki en España, in: A.H.D.E. 7, 1-167

- López-Ortiz, José (1931), Figuras de jurisconsultos hispano-musulmanes, in: Religión y cultura 16, 94-104

- López-Ortiz, José (1932), La jurisprudencia y el estilo de los tribunales musulmanes de España, in: A.H.D.E. 9, 213-248

- Maalouf, Amin (2008), Les croisades vues par les arabes, Paris: J'ai lu

- Malik, Jamal (1999), Muslimische Identitäten zwischen Tradition und Moderne, in Gephart/Waldenfels (1999) 206-229

- Martín Gutierrez, Diego J. (n.d.), El Islam en Al-Andalus: Estructura jurídico-social y organización política, Material de Docencia de Centro Universitario de Algeciras, Centro Universitario de Estudios Superiores. Instituciones históricas en el Derecho español, last retrieved May 102014 from: http://www.historiadelderecho.es/

- Martínez Almira, Magdalena (1999), La dimensión jurídica del tiempo en el Muhtasar de Hallîl, Roma

- Martínez Dhier, Alejandro (2007a), Algunas consideraciones sobre la Historia del Derecho Musulmán en España, in: HiD 34, 189-206

- Martínez Dhier, Alejandro (2007b), Rafael de Ureña y Smenjaud y sus Observaciones acerca del desenvolvimiento de los estudios de Historia del Derecho español, Granada: Editorial Universidad De Granada

- Martínez Dhier, Alejandro (2010), Consideraciones jurídicas en torno a la etnia gitana en Aragón y Cataluña durante la época de la Monarquía Absoluta, in: Estratto dal volume Quaderni Fiorentini per la storia del pensiero giuridico moderno 39, 83-107

- Martínez Torres, José Antonio (2008), Circulación de personas e intercambios comerciales en el Mediterráneo y en el Atlántico (siglo XVI, XVII, XVIII), Madrid: Consejo Superior de Investigaciones Científicas

- Matar, Nabil (1998), Islam in Britain: 1558-1685, Cambridge: Cambridge University Press http://dx.doi.org/10.1017/ CBO9780511582738

- Matar, Nabil (1999), Turks, Moors and Englishmen in the Age of Discovery, New York: Columbia University Press

- Maziane, Leila (2007), Salé et ses corsaires (1666-1727). Un port de course marocain au XVIIe siècle, Rouen, Caen: Pôle universitaire normand

- Mead, George Herbert (1934), Mind, Self and Society, Chicago: University of Chicago Press

- Mendizabal Allende, Rafael de (1970), Estructura socioeconómica y Administración de la Justicia en la España musulmana, in: Boletin del Ministerio de Justicia, Histórico de Estudios Doctrinales 863, 3-18

- Merkur Online (2009), »Muselmann« kostet 1200 Euro, online article published on August 19 2009, last retrieved on May 17 2014 from: http://www.merkur-online.de/lokales/fuerstenfeldbruck/landkreis/muselmann-kostet-1200-euro-448656.html

- Morand, Marcel (1916), Avant-projet de code. Présenté à la Commission de codification du droit musulman algérien (Doyen de la Faculté de Droit de l'Université d'Alger. Membre associé de l'Institut Coloniale Internationale), Alger: Jourdan

- Müller, Christian (1999), Gerichtspraxis im Stadtstaat Cordoba. Zum Recht der Gesellschaft in einer malikitisch-islamischen Rechtstradition, Leiden: Brill

- Ost, François (2012), Shakespeare. La Comédie de la Loi, Paris: Michalon Éditions

- Pasnau, Robert (2011), Averroes. The Islamic scholar who gave Us West Modern Philosophy, in: Humanities 32,6 (2011), last retrieved on May 132014 from: http:/www.neh.gov/humanities/2011/novemberdecember/feature/the-islamic-scholar-whogave-us-modern-philosophy

- Pedani, Maria Pia (1994), In nome del Gran Signore. Inviati ottomani a Venezia dalla caduta di Costantinopoli alla guerra di Candia, Venezia 
- Pedani, Maria Pia (2010), Venezia porta d'Oriente, Bologna: Il Mulino

- Peláez Portales, David (1999), La Administración de Justicia en la España musulmana, Córdoba

- Peláez Portales, David (2000), El proceso judicial e la España musulmana (siglos VIII-XII), con especial referencia a la ciudad de Córdoba, Córdoba

- Perez Boyero, Enrique (1997), Moriscos y Cristianos en los señoríos del reino de Granada (1490-1568), Granada: Editorial Universidad

- Perez Villanueva, Joaquin, Bartolome Escandell Bonet (eds.) (1993), Historia de la Inquisición en España y America II. Las estructuras del Santo Oficio, Madrid: Biblioteca de Autores Cristianos - Centro de Estudios Inquisitoriales

- Perron, M. (1848-1854), Précis de jurisprudence musulmane ou principes de législations musulmanes civile et religieuse selon le rite malékite. Par Khalil Ibn Ishak, exploration scientifique de l'Algérie pendant les années 1840-1841-1842, 7 vol., publié par ordre du gouvernement et avec le concours d'une commission Académique, Paris: Imprimerie Nationale

- Potz, Richard (2011), Islam und islamisches Recht in der europäischen Rechtsgeschichte, in: Institut für Europäische Geschichte (ed.), Mainz, Europäische Geschichte Online, last retrieved on May 82014 from: http://www.ieg-ego.eu/potzr2011a-de

- Poumarède, Géraud (2004), Pour en finir avec la croisade. Mythes et réalités de la lutte contre les Turcs aux XVIe et XVII siècles, Paris: PUF

- Remie Constable, Olivia (1994), Trade and Traders in Muslim Spain. The commercial realignment of the Iberian peninsula, 900-1500, Cambridge: Cambridge University Press

- Ribera, Julián (1914), Historia de los jueces de Córdoba por Aljoxaní, texto árabe y trad. Española, Madrid

- Roy, Olivier (1999), Vers un islam européen, Paris: Esprit

- Sakrani, Raja (2008), Codifier la morale? La morale dans les Codes civils français et tunisien, in: Revue international de droit comparé 2, 461-485 http://dx.doi.org/10.3406/ridc.2008.19821

- Sakrani, Raja (2009), Au croisement des cultures de droit occidentale et musulmane. Le pluralisme juridique dans le code tunisien des obligations et des contrats, vol. 15, Hamburg: EB

- SaKrani, Raja (2012), Des ordres normatifs fragmentés à l'hybridité juridique: le cas du Maghreb colonial, in: GePHaRT (ed.) (2012a) 231-265

- Sakrani, Raja (2013), Religion als Legitimation einer Geltungskultur? Islamische Rechtskulturen in Europa im Wandel, in: Pfleiderer, Georg, Alexander Heit (eds.), Religions-Politik I. Zur historischen Semantik europäischer Legitimationsdiskurse, Zürich: Nomos

- Sánchez Albornoz, Claudio (1946), La España musulmana según los autores islamistas y cristianos medievales, Buenos Aires

- Sánchez Albornoz, Claudio (1956), España: un enigma historico, 2 vol., Buenos Aires

- Sartre, Jean-Paul (1962), Huis-clos, Paris: Prentice-Hall

- Scaraffia, Lucetta (1993), Rinnegati. Per una storia dell'identità occidentale, Rome: Laterza

- Schlosser, Hans (2012), Neuere Europäische Rechtsgeschichte. Privat- und Strafrecht vom Mittelalter bis zur Moderne, München: Beck

- Schmoeckel, Mathias (2005), Auf der Suche nach der verlorenen Ordnung. 2000 Jahre Recht in Europa - Ein Überblick, Köln: Böhlau

- Schulze, Hagen (1995), Staat und Nation in der europäischen Geschichte, $2^{\text {nd }}$ ed., München: Beck

- Ureña Y Smenjaud, Rafael de (1906a), Estudios de litaratura jurídica, Madrid: Moreno

- Ureña Y Smenjaud, Rafael de (1906b): Historia de la literatura jurídica española. Sumario de las lecciones dadas en la Universidad central durante el curso de 1897 a 98 y siguientes, Madrid: Idamor Moreno

- Valensi, Lucette (1967), Esclaves chrétiens et esclaves noirs à Tunis au XVIIIe siècle, in: Annales ESC 6, 1267-1288

- Valensi, Lucette (2012), Ces étrangers familiers, Musulmans en Europe (XVIe-XVIIIe siècles), Paris: Rivages et Payot

- Van Eerde, Johan Christiaan (1927), Ethnologie coloniale. L'européen et l'indigène, Paris: Du Monde Nouveau

- Vespertino Rodríguez, Antonio (1987-1989), Una aproximación a la datación de los manuscritos aljamiado-moriscos, in: Estudios Románicos. Homenaje al profesor Luis Rubio, Murcia: Univ. de Murcia II, 1419-1439

- Vidal Naquet, Pierre (2009), La démocratie grecque vue d'ailleurs, Essais d'historiographie ancienne et moderne, Paris: Flammarion

- Vila, Salvador (1931), Abenmoguit, ,formulario notariak, capítulo de matrimonio, in: A.H.D.E. 8, 6-200

- Vila, Salvador (1933), Un contrato de matrimonio entre musulmanes en el siglo XVI, in: A.H.D.E. 10, 186-196

- Vincent, Bernard (2001), Les études morisques. 400 ans après l'expulsion, in: IBLA, Revue de l'Institut des belles-lettres arabes $1,205,81-93$

- Voelke, André-Jean (1961), Les rapports avec autrui dans la philosophie grecque d'Aristote à Panétius, Paris: Vrin

- Wesel, Uwe (2010), Geschichte des Rechts in Europa: Von den Griechen bis zum Vertrag von Lissabon, München: Beck

- Wieacker, Franz (1967), Privatrechtsgeschichte des der Neuzeit, $2^{\text {nd }}$ ed., Göttingen: Vandenhoeck $\&$ Ruprecht

- Wiegers, Gerard (1994), Islamic literature in Spanish and Aljamiado. Yça of Segovia. His Antecedents and Successors, Leiden: Brill 